http://kitaibelia.unideb.hu/

ISSN 2064-4507 (Online) • ISSN 1219-9672 (Print)

(C) Department of Botany, University of Debrecen, Hungary

22 (2): 358-382.; 2017

DOI: $10.17542 /$ kit.22.358

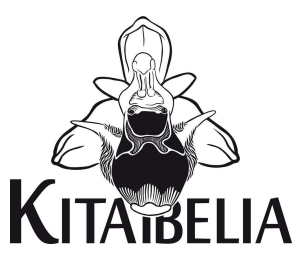

\title{
Pótlások Magyarország edényes növényfajainak elterjedési atlaszához IV.
}

\author{
Kevey Balázs \\ Pécsi Tudományegyetem, Ökológiai Tanszék, H-7624 Pécs Ifjúság útja 6. \\ keveyb@gamma.ttk.pte.hu
}

\section{Contributions to the Atlas Florae Hungariae IV.}

\begin{abstract}
The paper lists supplementary data to the recently published Atlas Florae Hungariae, mostly from various parts of Transdanubia and the Great Plain. The list includes 72 plant species with at least one new station not shown on their grid-based range map. Certain data confirm old records, whereas some others correct erroneous distribution data. The actual habitats where the plants occur are characterized by their corresponding ÁNÉR codes.
\end{abstract}

Keywords: Hungary, floristic surveys, ÁNÉR habitat codes

Összefoglalás - Jelen dolgozat a nemrég megjelent magyarországi flóraatlaszhoz tartalmaz kiegészítő adatokat, elsősorban a Dunántúl és az Alföld különböző tájairól. A közlemény 72 növényfajról tartalmaz olyan florisztikai adatokat, amelyek a fajok elterjedési térképein új kvadrátban való előfordulásokat jelentenek. Egyes adatok régi előfordulásokat is megerősítenek, s a dolgozat néhány téves adatot is helyesbít. A növényfajok előfordulási viszonyait az ÁNÉR kódok dokumentálják.

Kulcsszavak: Magyarország, florisztika, ÁNÉR élőhelyek

\section{Bevezetés}

Nemrég jelent meg a várva-várt magyarországi flóraatlasz (BARTHA et al. 2015), amely alapján a fajok hazai elterjedéséről már lényegesen tisztább kép rajzolódik ki, mint korábban. Lapozgatva az oldalakat észrevettem, hogy számos új adattal tudnék hozzájárulni a fajok elterjedési térképének helyesbítéséhez. E kiegészítő adatokhoz elkezdtem böngészni régi jegyzeteimet és cönológiai felvételeimet, amelyek elsősorban a Dunántúl és az Alföld különböző tájegységeiről származnak az 1970-es évek elejétől napjainkig. Közöltem néhány olyan adatot is, amelyek előfordulását hosszú idő után sikerült megerősíteni. Adataim böngészése közben vettem észre, hogy a flóraatlaszban megjelent térképek nagy része bizony jelentős kiegészítésre szorul. A flóraatlaszban például a Vicia oroboides térképén 30 pontszerű előfordulás szerepel, amit ehelyütt újabb 18 ponttal egészítek ki. Az elterjedési térképekről az is érzékelhető, hogy egyes tájegységek milyen alapossággal lettek átkutatva. Megjegyezném még, hogy az 1970-es évek végén Borhidi professzor úr megbízásából elég sok - a Középeurópai Flóra térképezésére készített (NIKLFELD 1971) - űrlapot töltöttem ki, amelyek pár éve még Vácrátóton voltak. Úgy látom, hogy ezek nem kerülhettek át Sopronba, mert a rajtuk rögzített adatok túlnyomó része nem került bele a magyar atlaszba (BARTHA et al. 2015). Szükséges lenne továbbá a florisztikai és a cönológiai irodalom, valamint a herbáriumok 
olyan adatait is térképre vinni, amelyek a megadott településhatár és a dűlőnév alapján lokalizálhatók, ugyanis kár lenne mintegy két évszázad flórakutatási eredményeit figyelmen kívül hagyni. Mindezeken kívül még két apró javaslatom lenne a flóraatlasz második kiadásához. Egyrészt a kutakban, kőfalakon és egyéb emberi létesítményeken megjelenő páfrányok (pl. Asplenium scolopendrium, Asplenium trichomanes, Cytopteris fragilis, Polystichum aculeatum), feltüntetéséhez más jelet kellene használni, mint a természetszerű környezetben való előfordulásokhoz. Másrészt az 1951 és 1990 közötti adatokat nem kellene félig befeketített körrel jelölni, hanem teljesen befeketített körrel, mert ezek valójában nem igazán régi adatok, főleg az 1980 és 1990 közöttiek. Elég lenne az 1901 és 1950 közötti adatokat félig befeketített körrel, az 1900 előtti adatokat pedig körrel jelölni.

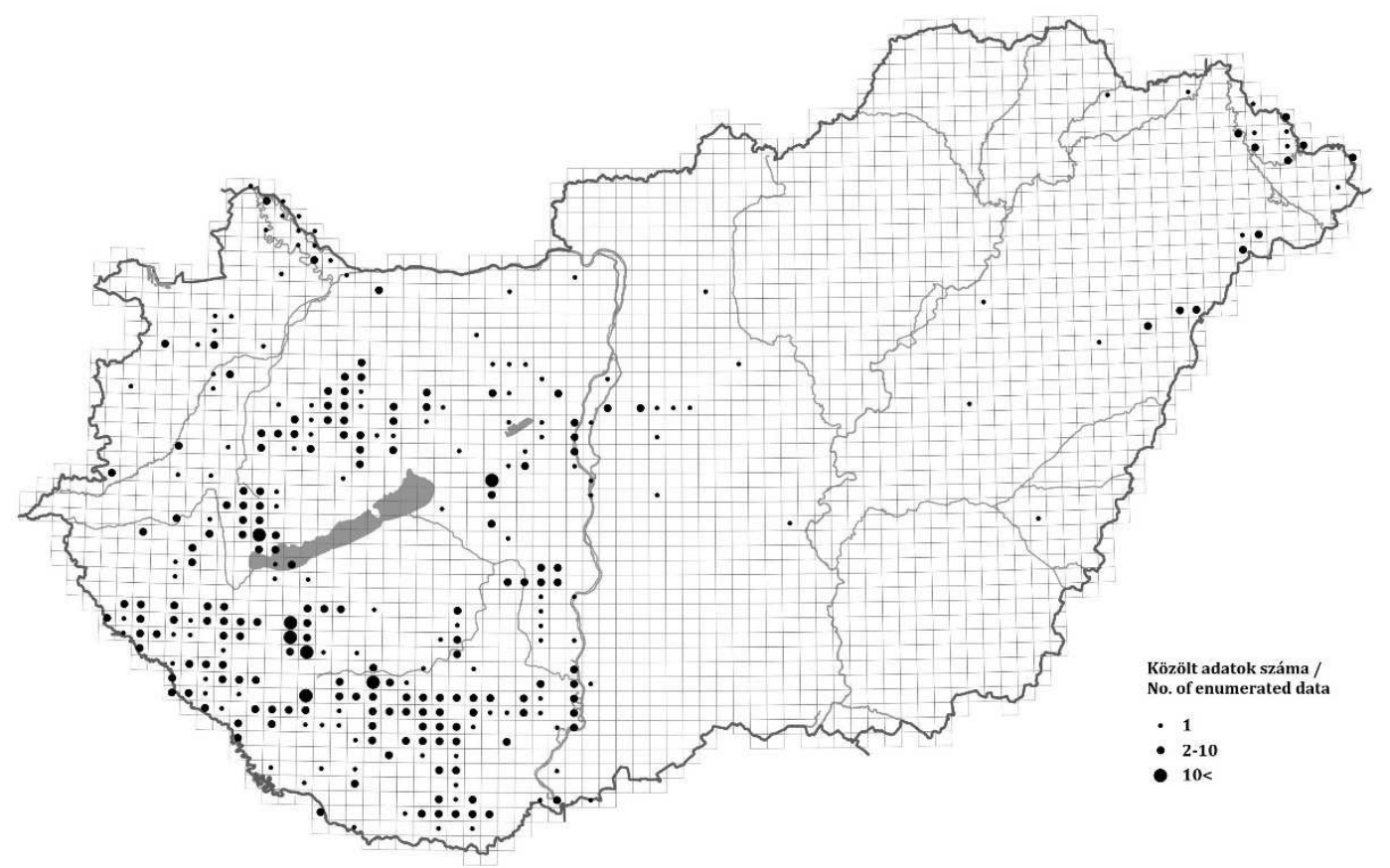

1. ábra. A közleményben összefoglalt előfordulási adatok a közép-európai flóratérképezés (KEF) hálórendszerének kvadrátjaira vetítve (szerkesztette: Takács A.)

Fig. 1. Distribution of localities of presented data, projecting for the quadrates of the Central European flora mapping system (CEU) (edited by A. Takács)

A fajok esetében KIRÁLY (2009) nomenklatúráját követem. Felsorolásuk a könnyen áttekinthető $\mathrm{ABC}$ sorrendben történik azzal a különbséggel, hogy az alábbi három rendszertani kategóriát megtartottam: Pteridophyta, Dicotyledonopsida, Monocotyledonopsida. Az elterjedési adatokat a Közép-európai Flóratérképezés raszterkódjai (NIKLFELD 1971) alapján tűntetem fel. A fajok felsorolásánál megjelölöm a földrajzi táj nevét, a települési határt, a dűlőnevet, az ÁNÉR kódok (BöLÖNI et al. 2011) szerinti élőhelyet, az első megtalálás évszámát, illetve a korábban közölt lelőhely esetében hivatkozom a szóbanforgó tanulmányra. 


\section{Enumeráció}

Pteridophyta

Asplenium adiantum-nigrum L. - Khg: 9069/3: Zalaszántó „Kovácsi-hegy” LY2 (K: 2005). 9169/1: Rezi „Hosszú-völgy” LY2 (K: 1984). BS: 9568/2: Galambok „Vincédi-erdő” J6 (K: 2014).

Asplenium scolopendrium L. - Vshg: 8279/3: Dömös „Rám-szakadék” LY1 (K: 1981). Khg: 9169/3: Cserszegtomaj „Csóka-kő” LY1, LY2 (K: 1991). 9169/4: Vállus „Szent-Miklósvölgy” LY1, LY2 (K: 1985), „Csetényi-erdő” LY1, LY2 (K: 2002). ÉZ: 9267/2: Rádó „Kő-hegy: Konyhászói-erdő” LY1 (K: 1992). DZ: 9466/1: Lasztonya (KÁROLYI 1949: 18) „Borshelyárok” LY1 (PócS in KÁROLYI \& PócS 1968: 364; KEVEY 2008a: 44/7. táblázat). 9468/1: Újudvar „Csibiti-völgy” LY1 (KEveY 2008a: 44/7. táblázat). 9468/4: Zalakaros „Szőlö-hegy” LY1 (K: 1991). 9566/1: Murarátka „Rátkai-hegy” LY1 (Lelkes ex verb.: 2006). Zd: 9767/2: Őrtilos „Vasút-oldal: Páfrányos” LY1 (KEvEY 1988: 94). Zs: 9672/3: Kaposmérő „Bárdi-bükk felé, idős löszárokban” LY1 (Jávorka S. in BP: 1927). 9772/2: Bőszénfa „Ropolyi-erdő” LY1 (Z.-Horváth J. in Kevey 2010: 40; Z.-HoRvÁth J. in Kevey 2013c: 35). 9773/3: Bőszénfa „Paphegy” LY1 (NÉMETH in KeVEY 2010: 40; NÉMETH in KEVEY 2013c: 40). 9773/4: Gálosfa „Sárközi-erdő" LY1 (KeVEY 2010: 40; KEVEY 2013c: 35), „Csepegő-kő” LY1 (NovACSEK in KEVEY 2010: 40; NovACSEK in Kevey 2013c: 35). Vlhg: 0176/1: Nagytótfalu „Császár-hegy” LY1 (KeVEY 1983: 19).

Asplenium septentrionale (L.) Hoffm. - Mcs: 9875/2: Hosszúhetény „Köves-tető” LY2 (K: 2009). Mintegy $10 \mathrm{~cm}$ sugarú kör mentén egy kis populáció! 9974/2: Kővágószőlős „Babásszerkövek" LY4 (K: 2003).

Equisetum fluviatile L. em. Ehrh. - Sz: 8069/2: Dunakiliti-Tejfalusziget „Zátonyi-Duna” (AleXAY in Kevey 1993a: 54). 8170/4: Hédervár „Vadaskerti-erdő” J2 (AlEXAY \& KeVEY in KEVEY 1993a: 54). BSzS: 7800/3: Jánd „Holt-Tisza” J4 (KevEY \& BARNA 2015: 90). 7901/1: Tivadar „Dorongó” J4 (KEvEY \& BARNA 2015: 90).

Equisetum hyemale L. - Mf: 9378/1: Bikács-Kistápé „Akalacsi-erdő, helyesebben Csordamező" K1a (KeVEY 1983: 19; KEVEY in KeVEY \& LENDVAI 2015: 24). Cssz: 8779/3: Szigetújfalu „Újfalusi-erdő” J6 (K: 1978). Sk: 9679/1: Bogyiszló „Orchideás-erdő” (PILISI in KEVEY 1995: 45). 9679/3: Szekszárd „Gemenc” J6 (Kevey 1995: 45). 9879/1: Baja „Pörbölyi-erdő” J6 (SimON \& STETÁK in STETÁK 2000: 155). Msz: 9978/4: Homorúd „Riha-tó” (Deme ex verb.: 2003). Ba: 8572/4: Gic „Gerencséri-erdő” J5 (KeveY 2015b: 63). ÉZ: 9168/3: Tilaj „Zalacsányi-patak” J5 (KeveY 1995: 45). BS: 9570/4: Böhönye-Dávodpuszta „Cífra-malom: Halászház” J5 (Kevey, Horvát A. 0., Novacsek ined.: 1974), „Tranglus-erdő” K1a (KEVEY 2013a: 32). 9570/2: Mesztegnyo „Búsvár” K1a (Kevey 2013a: 32). 9571/3: Nagybajom „Fehér-tó” J5 (K: 1996). 9469/3: Zalakomár-Ormándpuszta „Csöngő-kút” J6 (K: 1990). 9469/4: Szőkedencs „Csörgető” J6 (K: 1998). Zs: 9673/3: Sántos „Herceg-forrás” J5 (K: 2010). Mcs: 9776/3: Magyaregregy „Vár-völgy” J5 (K: 2006). 9875/3: Pécs „Melegmányivölgy" J5 (K: 1983).

Equisetum telmateia Ehrh. - BDs: 0175/3: Kovácshida „Külső-Szödöny” (KEvEY 1995: 45). Mf: 9177/3: Pusztaegres „Őrspuszta” J6 (KevEY 1988: 93). KTv: 9185/2: Lakitelek-Tőserdő „Nagy-tó” (VöRöss 1988: 122; Boros in VöRöss 1988: 122; KisS in VöRöss 1988: 122). B: 8771/2: Bakonyjákó-Iharkút „Sármás” J5 (K: 2015). 8771/4: Bakonyjákó „Németbánya felé, a Bittva-patak mentén” J5 (K: 2015). Khg: 9069/3: Zalaszántó „Kovácsi-hegy” J5 (K: 2000). 9169/4: Vállus „Csetényi-erdő” J6 (K: 2015), „Barbacsi-erdő” J5 (K: 2015). DZ: 9668/2: Iharosberény „Szentpáli-erdő” J6 (K: 1987). BS: 9469/3: ZalakomárOrmándpuszta „Csöngő-kút” J5, J6 (K: 1990). 9470/4: Marcali „Nagy-Gyóta” J6 (K: 1991). 9471/1: Nikla „Bükkösd” J6 (K: 1990). 9771/1: Nagykorpád „Mórici-erdo”” J5 (K: 1988). Zs: 
KEVEY (2017): Pótlások Magyarország edényes növényfajainak elterjedési atlaszához IV.

9772/2: Bőszénfa „Ropoly” LY1 (KeVEy 2010: 39; KEVEY 2013c: 35). 9773/1: Gálosfa „Vörösalma-erdő” J6 (K: 2016). 9774/1: Baranyajenő „Kósa-gödör” K1a (K: 1996). 9774/2: Meződ „Lodac” J6 (K: 1990).

Gymnocarpium dryopteris (L.) Newman - K: 8968/3: Mikosszéplak „Mikosdi-erdő” K2 (K: 1991). BS: 9470/4: Marcali „Nagy-Gyótai-erdő” K5 (KeVEY in KEVEY et al. 1998: 251). 9669/3: Szenta „Baláta-tó” K1a (Borhidi \& Kevey ined.: 1990). Mcs: 9776/3: Máza „Mázaivízárok” K5 (KEVEY 1990: 85), „Vörös-domb” K5 (Kevey \& Csete ined.: 2014). 9875/2: Mánfa „Száraz-gödör” LY1 (KEVEY 1993a: 54). Gd: 8778/3: Bátaszék „Kövesdi-erdő” (TóTH I. Zs. in KeVEY 1993a: 54).

Lycopodium clavatum L. - BS: 0071/1: Darány „Ősborókás” (K: 1987). 9870/1: Rinyaszentkirály „Ág-erdo” S5 (K: 1997). Mcs: 9875/4: Pécs-Somogy „Hármas-bükk” L4a (Kurucz ex verb.: 1999).

Marsilea quadrifolia L. - Sk: 9679/4: Őcsény „Forgó-tó” Ac (TóTH I. 1958: 129). 9879/1: Baja „Alsó-Pörböly” Ac (TóTH I. 1958: 129), „Alsó-Pörböly: a Csörösz kivezető árkában” Ac (Tóth I. in Kevey \& TóTH I. 2000: 133), „Felső-Pörböly” Ac (TóTH I. in Kevey \& TóTH I. 2000: 133). Msz: 0078/4: Kölked „Macskalyuk” Ac (KeveY in KeVEY \& O.KovÁcs et al. 1992: 15). 0079/4: Hercegszántó-Karapancsa „Halas-tó” Ac (KÁRPÁTI V. 1963: 379), „a Keskeny-erdő melletti halastóban" Ac (BoRHIDi in KeveY \& TóTH I. 2000: 133).

Ophioglossum vulgatum L. - Sz: 8069/2: Rajka „Diós” J5 (KeVEY in KeVEY \& AlEXAY 1992: 30; KeVEY 1993a: 54). 8272/3: Nagybajcs „Csápolnok” J1a (AlEXAY in KeVEY \& AleXAY 1992: 30; AleXAY in KeVEY 1993a: 54). SDs: 9768/3: Gyékényes „Lankóci-erdo”” J1a, J6 (KeVEY 2007c: 105). Mf: 9278/3: Cece „Felsőmenyőd” J1a (LendVAI in Kevey 1995: 46), „Hardi-patak” J1a (KEVEY \& LENDVAI in KEVEY 1990: 85). 9378/2: Németkér „Látó-hegy” J1a (KALOTÁS in KevEY 1995: 46). Cssz: 8779/4: Szigetújfalu „a Duna melletti erdőben” J6 (Boros 1970: 71), „Újfalusi-erdő” J6 (K: 1978). Sk: 9679/1: Bogyiszló „Orchideás-erdő” S2 (KALOTÁs \& ZÖRÉNYI in Kevey \& Tóth I. 2000: 133). 9679/3: Őcsény „Gemenc” J6 (TóTH I. in Kevey \& TóTH I. 2000: 133), „Keselyűs” J6 (TóTh I. in Kevey \& TóTH I. 2000: 133), „Makkos-part” J6 (TóTH I. in Kevey \& Tóth I. 2000: 133), „Sáros-alja” J6 (TóTH I. in KeveY \& TóTH I. 2000: 133), „Zsoldkert” J6 (Tóth I. in Kevey \& Tóth I. 2000: 133). 9779/1: Decs „Gyöngyös-oldal” J6, K1a (Tóth I. 1958: 129). 9779/3: Decs „Keskeny-erdő” J6, K1a (Kevey \& TóTH I. in Kevey 1995: 46). - Baja „Cserta” J6 (Tóth I. 1958: 129), „Kis-Rezét” J6 (Mórocz in STETÁK 2000: 162). 9879/1: Báta „Gyűrűsalj” J4, K1a (KeveY in KeVeY \& TóTH I. 2000: 133). - Baja „Pörbölyierdő” (BALANYI \& MóRocz in STETÁK 2000: 162), „Közép-Pörböly” J6 (TóTH I. 1958: 129), „Nyéki-Holt-Duna” (SiMON \& STETÁK in STETÁK 2000: 162), „Pandúr-sziget” (KoHÁRI, MolnÁR Zs., STETÁK \& ToBisCH in STETÁK 2000: 162). DTk: 8881/2: Dabas „Turjános” J6 (K: 2016). Ny: 8496/4: Debrecen „Halápi-erdo”” J6 (KeveY \& PAPP L. ined.: 2003). 8497/2: Nyíracsád „Jónás-rész” J6 (KEVEY \& PAPP L. ined.: 2003). 8498/1: Nyírábrány „Kiskőrises” J6 (KEVEY \& PAPP L. ined.: 2007). BSzS: 7700/1: Tiszakerecseny „Lónyai-erdő” J6 (K: 2010). 7903/1: Magosliget „Fischer-erdő=Cserköz-erdő” J6 (KEVEY 2004: 14). Mcs: 9973/2: Szentlőrinc „Aszai-árok” J1a (Kevey 2004: 14). Vlhg: 0176/2: Villánykövesd „Fekete-hegy” K2 (KEVEY 1993a: 54).

Polypodium vulgare L. - B: 8672/3: Ugod-Huszárokelőpuszta „Gerence-völgy: Delelő-árok” LY2 (K: 1995). 9069/2: Csabrendek „Rendeki-hegy” LY2 (K: 2006). Khg: 9169/3: Cserszegtomaj „Csóka-kő” LY1, LY2 (K: 1991). 9169/4: Vállus „Szentmiklós-völgy” LY1, LY2 (K: 1985), „Csetényi-erdo”” LY1, LY2 (K: 1999). 9269/2: Balatongyörök „Kígyós-völgy” LY2 (K: 2004). DZ: 9466/1: Lasztonya „Cigány-árok” LY1 (KeVEY 2008a: 44/7. táblázat). 9468/1: Újudvar „Csibiti-völgy” LY1 (KEVEY 2008a: 44/7. táblázat). 9566/1: Kistolmács „Fintai-erdő” K5 (K: 2009). BS: 9869/3: Bélavár „Kerék-hegy” K5 (KEVEY in KeveY et al. 1998: 247); „a Palinai-erdő felé vezető út melletti erdőben” K5 (KeVEY in KevEY et al. 1998: 247). Zs: 9773/4: Gálosfa „Csepegő-kő” LY1 (KeveY 2010: 40; KEvEY 2013c: 35). Vlhg: 
0176/2: Nagyharsány „Szársomlyó” M1 (K: 1987). Gd: 9877/3: Geresdlak „Kisgeresdierdő: Disznós-árok" LY1 (K: 2006).

Polystichum aculeatum (L.) Roth - B: 8772/3: Hárskút „Fehérkő-árok” LY1, LY2 (K: 1996). Khg: 9169/1: Rezi „Hosszú-völgy” LY1, LY2 (K: 1984), „Púpos-hegy” LY2 (K: 1984). 9169/3: Cserszegtomaj „Csóka-kő” LY1, LY2 (K: 2000). 9169/4: Vállus „Szentmiklós-völgy” LY1, LY2 (K: 1985), „Csetényi-erdő” LY1, LY2 (K: 2002); Balatongyörök „Pad-kő-árok” LY1 (K: 2003). 9270/1: Balatonederics „Edericsi-hegy” LY2 (K: 1982). ÉZ: 9267/2: Rádó „Kőhegy: Konyhászói-erdő" LY1 (K: 1992). DZ: 9468/1: Nagybakónak „Tukora” LY1 (KeveY 2008a: 44/7. táblázat). BS: 9568/2: Galambok „Vincédi-erdő” J5 (K: 2014). KS: 9572/4: Somogyaszaló „Déshidai-parkerdő” K1a (K: 1977). Zs: 9673/3: Kaposvár „Hangyás-mál” LY1 (KeveY 2010: 40; KevEY 2013c: 35); Sántos „Herceg-forrás” LY1 (KeveY 2010: 40; KEveY 2013c: 35), „Öreg-hegy” LY1 (KeVEY 2010: 40; KEVEY 2013c: 35); Cserénfa „Alja-patak” LY1 (Kevey 2010: 40; Kevey 2013c: 35), „Göllénfa” LY1 (Kevey 2010: 40; KeveY 2013c: 35). 9773/4: Gálosfa „Sárközi-erdő” LY1 (Kevey 2010: 40; Kevey 2013c: 35). 9774/3: Palé „Nagy-hegy” K2 (K: 1984). Mcs: 9874/2: Bodolyabér „Koch-malom” LY1 (KeVEY 1997: 94). 9874/3: Bakonya „Sás-völgy: Pósa-völgy” LY1 (KevEY 1997: 94). - Hetvehely „Nyáras-völgy: Nyáras-forrás” LY1 (KeveY 1997: 94), „Nyáras-völgy: Szarvas-kút” LY1 (KEVEY 1997: 94). 9875/1: Bános „Nagy-kő-oldal” LY1 (KeveY 1997: 95). - Mánfa „Mély-völgy: Kő-lyuk” LY1 (KevEY 1997: 95), „Kőfejtő-kút” LY1 (KevEY 1997: 95). 9875/2: Mánfa „Nagy-forrás-völgy” LY1 (Kevey 1997: 95), „Rákos-völgy” LY1 (KeveY 1997: 95). Gd: 9778/3: Bátaapáti „NagyMórágyi-völgy" LY1 (K: 2003).

Polystichum setiferum (Forskål) Moore ex Woynar - BDs: 0072/2: Bürüs „Keselőc” K1a, K5 (KeVEY 2007b: 50). 0171/2: Lakócsa „Alsó-erdő" K1a (KeVEY 2007b: 50). B: 8672/3: Bakonybél „Gerence-völgy: Delelő-árok” LY1 (K: 2010). 8772/2: Bakonybél „Som-hegy” LY2 (K: 2011). 8772/3: Hárskút „Szekrényeskő-árok” LY2 (K: 1996). 8872/1: Hárskút „Középső-Hajag” LY2 (K: 2008). 8872/2: Hárskút „Fehérkő-árok” LY1, LY2 (K: 1996). 8872/4: Szentgál „Bece-kő” LY2 (K: 2006). Khg: 9169/1: Rezi „Hosszú-völgy” LY1 (KEvEY 1988: 94). 9169/3: Cserszegtomaj „Csóka-kő” LY1 (K: 2000). 9169/4: Balatongyörök „Padkő-árok” LY1 (K: 2003). ÉZ: 9166/3: Böde „Bödei-völgy” LY1 (K: 2005). 9267/2: Rádó „Kőhegy: Konyhászói-erdő” LY1 (K: 1992). DZ: 9465/2: Páka-Dömefölde „Fejérlakosai-erdő” LY1 (KeveY 2008a: 44/7. táblázat); Tormafölde „Angyalirta-árok” LY1 (KeveY 2008a: 44/7. táblázat). 9465/4: Tormafölde "Centrale” LY1 (K: 2012). 9466/1: Lasztonya „Cigány-árok” LY1 (KEVEY 2008a: 44/7. táblázat); Lispeszentadorján „Diós-völgy” LY1 (KevEY 2008a: 44/7. táblázat). 9467/3: Eszteregnye-Obornak „Márki-erdő” LY1 (Kevey 2008a: 44/7. táblázat). 9468/1: Újudvar „Csibiti-völgy” LY1 (KEVEY 2008a: 44/7. táblázat); Nagybakónak „Tukora” LY1 (KeveY 2008a: 44/7. táblázat). 9468/2: Zalakaros „Kanica-erdő” LY1 (KEvEY 2008a: 44/7. táblázat). 9566/1: Letenye „Csitári-erdő” LY1 (KEVEY 2008a: 44/7. táblázat), „Kecskeháti-völgy” LY1 (KevEY 2008a: 44/7. táblázat). BS: 9570/2: Mesztegny” „Dávodierdő erdőrezervátum” K1a (KevEY 2013a: 32). Zs: 9673/3: Kaposvár „Hangyás-mál” LY1 (Kevey 2010: 40; Kevey 2013c: 35), „Vas-kapu” LY1 (Kevey 2010: 40; Kevey 2013c: 35); Sántos „Herceg-forrás” LY1 (KeveY 2010: 40; Kevey 2013c: 35), „Öreg-hegy” LY1 (KevEY 2010: 40; KeveY 2013c: 35); Cserénfa „Alja-patak” LY1 (Kevey 2010: 40; KeVEY 2013c: 35), „Göllénfa” LY1 (Kevey 2010: 40; Kevey 2013c: 35). 9673/4: Szentbalázs „Kóta” LY1 (K: 1984). 9772/2: Bőszénfa „Ropoly” LY1 (Kevey 2010: 40; KeveY 2013c: 35). 9773/3: Bőszénfa „Farkaslaki-erdő” K2 (Horvát A. O. ined.: 1976). 9774/3: Palé „Nagy-hegy” K2 (K: 1984). V: 9775/3: Kisvaszar „Bikági-völgy” K1a (KeveY 1988: 95). Vlhg: 0176/1: Nagytótfalu "Császár-hegy” LY1 (KEvEY 1985b: 27). Gd: 9777/3: Ófalu „Arany-völgy” LY1 (K: 2006). 9877/3: Geresdlak „Disznós-völgy” LY1 (K: 2006).

Thelypteris palustris Schott - Sz: 8271/1: Dunaszeg „Dunaszegi-tó” J1a (K: 1997). Mf: 9278/4: Németkér „Barát-erdő” J2 (KeveY \& TóTH I. Zs. 2016: 19). 9378/2: Németkér 
„Fekete-tó” J1a, J2 (Kevey \& TóTh I. Zs. 2016: 19). DTk: 8781/2: Ócsa „Ómér-erdő” J2 (K: 2016). Ny: 8100/3: Mérk „Vadaskerti-erdő” J2 (Kevey, Lendvai \& Papp L. ined.: 2005). 8497/2: Nyíracsád „Jónás-rész” J2 (Kevey \& Papp L. ined.: 2003). 8498/1: Nyírábrány „Mogyorósi-erdő” J1a, J2 (Kevey \& Papp L. ined.: 2003). Zd: 9667/3, 9767/1, 9767/2: Őrtilos „Visszafolyó-patak” J2 (KeveY \& Toldi in Kevey 2004: 15). BS: 9470/4: Marcali „KisGyóta” J1a, J2 (K: 2008). 9570/2: Hosszúvíz „Színai-berek” J1a, J2 (K: 2008). - Mesztegnyő „Dávodi-erdő erdőrezervátum” J1a, J2 (K: 2008). 9770/4: Lábod „Grófi-erdő” J2 (K: 2009).

\section{Dicotyledonopsida}

Aconitum vulparia Rchb. - B: 8672/2: Bakonyszentlászló „Pagonyi-erdő: Hódos-ér” J5 (K: 2002). 8672/3: Ugod-Huszárokelőpuszta „Gerence-völgy” J5 (K: 1996). 8771/3: Németbánya „Bittva-patak” J5 (K: 2015). 8774/2, 8775/1: Isztimér „Burok-völgy” LY1 (K: 1974). 8873/4: Veszprém „Csatár-hegy” K2 (K: 1999). Ba: 8672/1: Pápateszér „Mehetősierdő" K2 (Kevey 2015b: 62). 8771/1: Pápakovácsi „Attyai-erdő” K1a (K: 2003). 8870/4: Borszörcsök „Csigere-patak” K1a (K: 2012). Khg: 9069/4: Lesenceistvánd-Uzsa „Hubertusz” J5 (K: 1993). 9169/2: Zalaszántó „Vár-berek” J5, J6, K1a (K: 1988). DZ: 9468/4: Zalakaros „Szőlő-hegy” K2, K5 (K: 1991). 9568/2: Nagyrécse „Virág-hegy” J5, K2, K5 (K: 1978). 9667/2: Miklósfa „Szaplányosi-erdő” K1a, K5 (K: 1987). BS: 9569/1: Somogysimonyi „Gödörberki-erdő” J5, J6, K1a (K: 1998). 9570/2: Mesztegny” „Dávodi-erdő erdőrezervátum” J5, K1a, K5 (KeveY 2013a: 30), „Búsvár” J5, K1a (K: 1993). 9570/4: Böhönye „Dávodpuszta: Halászház” J5 (K: 1991), „Tranglus-erdő” K1a (KEvEY 2013a: 30). 9571/1: Mesztegny” „Felső-Kak” J5, K1a, K5 (KEVEY 2013a: 30). 9571/3: Nagybajom „Fehér-tó” J5, K1a (K: 1988), „Bükk” K1a, K5 (K: 1992). 9669/4: Somogyszob „Rinya-erdő: Kis-mező" K1a, K5 (KeveY 2013a: 30). 9771/1: Nagykorpád „Mórici-erdő” J5, K1a (KEVEY 2013a: 30). 9771/3: Mike „Patkány-domb” J5, K1a (K: 1996). Zs: 9872/1: Visnye „Boroserdő" K1a (K: 2016). Bd: 9975/3: Kökény „Malom-völgy” K2 (K: 1994).

Actea spicata L. - Ny: 8299/2: Bátorliget „Veres-folyás” J6 (KeVEY 1988: 96). Khg: 9169/1: Rezi „Hosszú-völgy” LY1, LY2 (K: 1984), „Hosszú-hegy” K2, K5 (K: 1984). 9169/3: Cserszegtomaj „Csóka-kő" LY1, LY2 (KevEY: 1991). 9169/4: Vállus „Barbacsi-erdő” J5, K2, K5 (K: 1986), „Szent Miklós-völgy” LY1, LY2, K2, K5 (K: 1985). 9269/2: Gyenesdiás „Büdöskúti-völgy” LY1, K2, K5 (K: 1986). DZ: 9467/1: Bucsuta „Börzöncei-hegy” K2, K5 (K: 2009). 9468/1: Újudvar „Csibiti-völgy” K2, K5, LY1 (KevEY 2008a: 44/4. táblázat). 9468/2: Zalakaros „Kanica-erdő” K2, K5, LY1 (KEVEY 2008a: 44/4. táblázat). 9468/4: Zalakaros „Szőlő-hegy” K2, K5 (K: 1991). 9667/2: Miklósfa „Szaplányosi-erdő” K2 (K: 1987). 9668/2: Iharosberény „Szentpáli-erdő” K2, K5 (K: 1987). 9668/4: Iharos-Ágneslak „Gágyi-erdő” K2, K5 (K: 2012). KS: 9472/1: Somogyvár „Télizöld” J5, K2 (K: 1998). BS: 9570/2: Mesztegny” „Mélyégeri-halastó” J5, K1a (K: 1993). 9571/1: Mesztegnyő „Mélyéger” K1a (KeveY 2013a: 31). 9869/3: Bélavár „a Palinai-erdő felé vezető földút melletti erdőben” K2, K5 (KEvEY in KEvey et al. 1998: 251), „Szőlő-hegy=Kerék-hegy” K2, K5 (KEvEY in KevEY et al. 1998: 251). Vlhg: 0175/2: Bisse "Remete” K2, K5, LY1 (KeveY 1985b: 27; KeVEY 1988: 96), „Poszhagymás” K2, K5 (KeveY 1987a: 1. táblázat), „Pécsi-lapis” K2, K5 (KeveY 1987a: 1. táblázat; KeVEY 1988: 96). - Kistótfalu „Átai-hegy” LY1, K2, K5 (KeVEY 1985b: 27; KeveY 1988: 96).

Adoxa moschatellina L. - Ks: 8373/1: Bőny „Bőnyi-erdő” K1a (Riezing 2011: 212; Kevey \& ALEXAY in KevEY 2015a: 42). Mm: 8869/2: Kiscsősz „Nagy-erdő” K1a (K: 2009). 8869/4, 8870/2: Tüskevár „Tüskevári-erdő” J6, K1a (K: 2011). 8869/4: Apácatorna „Galsai-erdő” J6 (K: 2013). 9069/1: Zalagyömörő „Nyirlakpuszta” J6 (K: 2011). 9070/1: Csabrendek „az Alcsabi templomrom melletti kicsiny erdőfoltban” J6 (K: 2013). R: 8468/2: Babót „Babóti- 
erdő” K1a (K: 2005). 8569/2: Szany „Szanyi-erdő” J6, K1a (K: 2005). 8668/2: Kenyeri „Nasici-erdő” J6 (K: 2004). VRv: 8668/3: Uraiúffalu „Rába-ártér” K1a (K: 2016). 8867/3: Zsennye „Zsennyei-erdő” J6 (K: 2016). Kv: 9465/2: Iklódbördőce „Cserta-erdő” J6, K1a (K: 2009), „Kerka-erdő” J6, K1a (K: 2011), „Cserta-torkolat” J6, K1a (K: 2011). SDs: 9869/3: Bélavár „Bereki-erdő” K1a (KeveY 2007a: 92). - Somogyudvarhely „Almási-erdő” K1a (K: 2000). BDs: 9972/4: Dencsháza „Hamuházi-erdő” K1a (KevEY 1981: 180). Mf: 8678/4: Martonvásár „Kastély-park” J6 (BoRos in KeveY 1987: 36). 9176/2: Dég „Park-erdő” J6 (KeveY 1981: 180; KeveY in PrISZTER 1980: 172). B: 8671/4: Ugod „Somberek” K2, LY4 (K: 2015). 8672/2: Bakonyszentlászló „Hódos-ér” J5 (K: 1999), „Cuha-völgy” LY1, LY2 (K: 1994). 8773/2: Bakonynána „Római-fürdő” J5, LY1 (K: 1996). 8872/2: Hárskút „Fehérkőárok” LY1, LY2 (K: 2012). 8972/2: Szentgál „Ôrszeg” K2 (K: 2000), „Felső-Zombor” K2, K5 (K: 2000), „Alsó-Zombor” K2, K5 (K: 2000). - Nemesvámos „Hárs-hegy” K2, K5, LY4 (K: 2000). 9069/2: Csabrendek „Rendeki-hegy” K2, K5, LY2, LY4 (K: 2006). - Sümeg „Fehérkövek” K2, K5, LY4 (K: 2005). 9070/3: Lesenceistvánd-Uzsa „Kisbakonyi-erdő” K1a (K: 2001). Khg: 9169/4: Vállus „Csetényi-erdő” J6, K2, LY1, LY2 (K: 1987), „Barbacsi-erdő” J5, K2, K5 (K: 1986). - Rezi „Fagyos-kereszt” K2, K5 (K: 1975). ÉZ: 9068/4: Vindornyaszőlős „Felső-erdő” K1a (K: 1993). DZ: 9566/2: Valkonya „a becsehelyi műút mellett” K5 (K: 2008). 9668/2: Iharosberény „Szentpáli-erdő” K2, K5 (K: 1987). 9568/2: Nagyrécse „Virághegy" J5, K2, K5 (K: 1974). 9566/2: Letenye "Júlián-hegy" K2, K5 (K: 2008). 9465/2: Tormafölde „Csokmai-erdő" K1a, K2 (K: 2012). KS: 9472/1: Somogyvár „Télizöld” J5, K2 (K: 1998). 9473/1: Kisbárapáti „Lucai-erdő” K2, K5 (K: 1993). BS: 9469/4: Csákány „Hertelendi-erdő" K1a (K: 1998). - Szőkedencs „Csörgető” J6, K1a (K: 1998). 9470/4: Marcali „Kis-Gyóta” J6, K1a (KeveY 2013a: 29), „Nagy-Gyóta” K1a, K5 (KeveY 2013a: 29). 9471/3: Libickozma „Kopári-erdő” K1a (KEvEY 2013a: 29). 9569/1: Galambok „Vincédierdő” J5, J6, K1a (K: 2014). 9570/2: Mesztegnyő „Búsvár” K1a (KeveY 2013a: 29), „Mélyégeri halastó” J5, J6, K1a (K: 1993), „Dávodi-erdő erdőrezervátum” J5, K1a, K5 (K: 1985). - Hosszúvíz „Színai-berek” J5, J6 (Kevey 2013a: 29), „Jegyzőírtás” J5, J6 (KeveY 2013a: 29). 9571/3: Nagybajom „Felső-Csikotai-erdő” J5, K1a, K5 (Kevey 2013a: 29). 9669/4: Somogyszob „Bükki-malom” J5, K1a, K5 (K: 1984). 9769/4: Nagyatád „Döbrögierdő” K1a (KeveY 2013a: 29). 9770/3: Nagyatád „Ámor-erdő” J6 (K: 1983), „Simongátierdő" K1a (K: 1990). 9771/1: Nagykorpád „Mórici-erdő” J5, K1a (Kevey 2013a: 29). 9771/3: Mike „Patkány-domb” J5, K1a (K: 1996). 9869/3: Bélavár „Kerék-hegy” K1a, K5 (KEVEY 2013a: 29). Mh: 9469/4: Somogyzsitfa-Szőcsénypuszta „Margit-sétány” J5 (K: 1996). Zs: 9673/3: Cserénfa „Tábor-völgy” J5, J6, K1a, K2, K5 (K: 1974). - Kaposvár „Nádasdi-erdő” J5, K1a, K2 (K: 1974), „Vaskapu” K1a, K2, K5, LY1 (Kevey 2010: 38; KevEY 2013c: 35). 9673/3: Sántos „Herceg-forrás” (Kevey 2010: 38; Kevey 2013c: 35). 9673/4: Szentbalázs „Hercegképe” J5, J6 (K: 2016). 9772/1: Bárdudvarnok-Lipótfa „Cseberki-erdő” J5, K1a, K2 (K: 2011), „Dennai-erdő” J5, J6, K1a, K2 (K: 2009). 9774/1: Baranyajenő „Kósagödör” K1a, K2 (K: 1996). 9774/1: Baranyajenő „Öreg-hegy” K1a, K2, K5 (K: 2000). 9774/4: Sásd „Herceg-erdő” K2, K5 (K: 2008). 9873/1: Almamellék „Szentgáli-hegy” J6, K1a (K: 1981). 9873/3: Mozsgó „Alsó-erdő” J6, K1a (K: 2015). V: 9775/1: Kisvaszar „Bikágivölgy” J5, K1a (K: 1978), „Hosszú-erdő” J5, K1a (K: 2004). 9775/2: Ág „Vágyom-völgy” J5, K1a (K: 1991). Mcs: 9874/2: Husztót „Husztóti-völgy” K1a (KeveY 2015d: 25). Magyarhertelend „Gödri-hegy: a termálfürdő feletti erdőben=Igaz-oldal” K2 (KEVEY 2015d: 25). 9874/3: Bükkösd „Pajtner-völgy” K2 (Kevey 2015d: 25). - Hetvehely „Sás-völgy” J5, K1a, K2 (Kevey \& BARANYI 2002: 16), „Nyáras-völgy” J5 (Kevey \& BARANYi 2002: 16). Bakonya "Sás-völgy” J6, K1a, K2 (K: 1980). 9875/2: Mánfa „Száraz-gödör” LY1, LY2, K2 (K: 1987). Vlhg: 0075/3: Turony „Sziget” K2 (K: 2010). 0075/4: Kistótfalu „Csicsó-hegy” K2 (KevEY 2016: 36). 0076/3: Vokány „Trinitás-erdő” J6, K2 (KEVEY 2016: 36). 0174/2: Diósviszló „Csikorgó” K2 (K: 1989). 0175/2: Bisse „Remete” K2 (Kevey 2016: 36), „Pécsi- 
lapis” K2 (Kevey 2016: 36), „Poszhagymás” K2 (Kevey 2016: 36). 0176/2: Nagyharsány „Szársomlyó” K2, LY2 (Kevey 2016: 36). Gd: 9877/3: Geresdlak „Kisgeresdi-erdő” K1a, K2 (K: 2004). 9777/4: Bátaapáti „Apáti-erdő” J5, K2 (K: 2000).

Anemone nemorosa L. - Ks: 8373/1: Bőny „Bőnyi-erdő” K1a (KevEY 2015a: 42). R: 8468/3: Himód „Alsó-erdő” K1a (K: 2005). 8568/1: Dénesfa „Dénesfai-erdő” J6, K1a (K: 2001). 8668/2: Kenyeri „Nasici-erdő” K1a (K: 2004). VRv: 8867/3: Rum „Rumi-erdő” J6, K1a (KevEY 2015e: 226). Mf: 8678/4: Martonvásár „Park-erdő” J6 (Kevey 1981: 180). 8976/4: Soponya-Nagyláng „Kastély-park” J6, K1a (KevEY 1983: 20). Cssz: 8879/1: Ráckeve „Besnyő” J6 (Kevey 1993a: 56 „Schilling-erdő” néven). Sk: 9779/3: Decs „Keskeny-erdő” J6, K1a (Tóth I. in KeVEY 1995: 46). SDs: 9869/1: Somogyudvarhely „Vecsenye” J5, J6, K1a (KevEY 2007a: 92). 9869/3: Somogyudvarhely „Almási-erdő” J6, K1a (Kevey 2007a: 92). Bélavár „Bereki-erdő” J6, K1a (KevEY 2007a: 92). Khg: 9069/3: Zalaszántó „Kovácsi-hegy” J5, K2, K5 (K: 1988). K: 8878/1: Káld „Avas-erdő” K1a, K5 (K: 1991). ÉZ: 9166/3: Böde „Bödei-völgy” LY1 (K: 2005). BS: 9669/4: Somogyszob „Rinya-erdő: Szénégető” K1a, K5 (KevEY 2013a: 31). 9769/4: Szenta „Kiskunovica” J5 (K: 1982). 9869/3: Bélavár „a Palinaierdő felé vezető út mellett=vasútmegálló melletti erdő" K1a, K5 (K: 1997). Zs: 9672/3: Szenna „Derék-hegy” K2 (K: 2008). 9673/3: Cserénfa „Tábor-völgy” J5, J6, K2, K5 (Horvát A. 0. \& Kevey ined.: 1974). - Kaposvár „Nádasdi-erdő” J5, K1a, K2, K5 (Horvát A. O. \& Kevey ined.: 1974). - Sántos „Herceg-forrás” J5, K2, K5, LY1 (KeveY 2010: 38; Kevey 2013c: 35). 9673/4: Szentbalázs „Kóta” J5, J6, K1a (K: 2016), „Hercegképe” J6, K1a, K2, K5 (K: 2016). Mcs: 9874/3: Hetvehely „Sás-völgy” J5, J6, K1a, K2 (Horvát A. O. \& Kevey ined.: 1974). Bükkösd „Pajtner-völgy” K2 (K: 2014). 9874/4: Abaliget „Csónakázó-tó” K2 (KeveY 1983: 20).

Aremonia agrimonioides (L.) DC. - Zs: 9672/3: Szenna "Derék-hegy” K2 (K: 2008). 9673/1: Kaposvár „Nádasdi-erdő” J6, K2 (K: 1981). 9673/3: Sántos „Herceg-forrás” K2 (K: 2000). Cserénfa „Tábor-völgy” K2, K5 (K: 1975). - Kaposvár „Vas-kapu” K2 (K: 2006). 9773/1: Kaposgyarmat „Lozsit-kút” K2, K5 (K: 1988). - Gálosfa „Vörösalma-erdő” K2 (K: 1977). 9773/3: Bőszénfa „Farkaslak” K2 (K: 1977), „Pap-hegy” K2 (K: 1984). 9774/1: Baranyajenő „Kósa-gödör” K1a (K: 1996), „Öreg-hegy” K2 (K: 2000). 9774/2: Sásd „Herceg-erdő” K2 (K: 2007), „Iván-völgy” K2 (K: 2007). 9873/3: Almamellék „,Szentgáli-hegy” K2 (K: 2000). Mcs: 9874/2: Magyarhertelend „Gödri-hegy: a termálfürdő feletti erdőben = Igaz-oldal” K2 (KEVEY 2015d: 27).

Aruncus dioicus (Walter) Fernald - DZ: 9466/1: Lasztonya „Borshely-árok” LY1 (KeVEY 2008a: 44/7. táblázat), „Cigány-árok” LY1 (KeveY 2008a: 44/7. táblázat). Lispeszentadorján „Diós-völgy” LY1 (KeveY 2008a: 44/7. táblázat). 9667/2: Miklósfa „Szaplányosi-erdő” (K: 1987). BS: 9869/3: Bélavár „a Palinai-erdő felé vezető földút melletti erdőben” K1a, K5 (KEveY in KevEY et al. 1998: 251), „Szőlö-hegy=Kerék-hegy” K1a, K5 (KeveY in KeveY et al. 1998: 251). V: 9775/2: Ág „Vágyom-völgy” LY1 (KeveY 1993a: 55). Mcs: 9875/1: Bános „Nagy-kő-oldal” LY1 (KEVEY 1997: 95), „Lóri-forrás” LY1 (K: 1983). Mánfa „Kő"lyuk” LY1 (KevEY 1997: 95). 9875/2: Mánfa „Száraz-gödör” LY1 (KevEY 1997: 95), „Nagy-forrás-völgy” LY1 (KEveY 1997: 95), „Kőszegi-forrás” LY1 (K: 2004). 9776/3: Óbánya „Óbányai-völgy” LY1 (KeveY 1993b: 46). - Vékény „Német-döglés” LY1 (KeVEY 1993b: 46).

Asperula taurina L. - Mcs: 9776/1: Kárász „Határ-oldal” K2, LY1 (Kevey 2014a: 102). 9875/4: Pécs „Árpád-tető” K2 (K: 1985).

Astrantia major L. - DZ: 9466/1: Lasztonya „Borshely-árok” LY1 (KeveY 2008a: 44/6. táblázat). BS: 9470/4: Marcali „Nagy-Gyóta” K1a (K: 1994). 9570/4: Böhönye-Dávodpuszta „Halastói-erdő” J5 (K: 1993), „Tranglus-erdő” K1a (KevEY 2013a: 31). - Nagybajom „Cífratanya és Dávodi-tó között” K1a (K: 1993). 9669/4: Somogyszob „Bükki-malom” K1a (K: 1975), „Kővölgyi-erdő” K1a, K5 (KeveY 2013a: 31). Zd: 9767/2: Örtilos „Vasút-oldal: Páfrányos” LY1 (Kevey 2008b: 40), „Lakos-völgy” J5 (Kevey 2009: 224; KEvEY 2013d: 242). 
- Zákány „Tölös-hegy” J5 (Kevey 2009: 224; KeVEy 2013d: 242). „Vasút-oldal: Hagymás” J6 (KeVEY 2012a: 18).

Cardamine amara L. - Sz: 8070/1: Dunasziget „Kormos” J4 (KeVEY in KeVEY \& AleXAY 1992: 32), „Vörös-füzes” J4 (KeveY in KeveY \& AleXAY 1992: 32). 8070/3: Dunasziget „Jakabsziget” J4 (Kevey in KeveY \& AleXaY 1992: 32). 8070/4: Dunasziget „llona-sziget” J4 (KeveY in KEVEY \& ALEXAY 1992: 32). - Kisbodak „Televény-sziget” J4 (K: 1990). 8170/2: Kisbodak „Öreg-sziget” J4 (KeVEY in Kevey \& ALEXAY 1992: 32). 8171/1: Lipót „Új-sziget” J4 (KeveY in KEVEY \& ALEXAY 1992: 32). 8171/3: Ásványráró „Senki-sziget és Árva-sziget között” J3 (Kevey in Kevey \& AleXay 1992: 32), „Dani-sziget” J3 (Kevey in Kevey \& AleXay 1992: 32). Má: 9465/3: Tornyiszentmiklós „Mura-erdő” J5 (K: 2010). Vé: 8476/3: Tatabánya „a Tüdőszanatórium melletti erdőben" J5 (K: 1995). A flóraatlasz (BARTHA et al. 2015: 105) a térképen 1950 előtti adatként jelöli. E helyen tehát ma is él a növény. Ba: 8572/4: Gic „Gerencséri-erdő" J5 (Kevey 2015b: 64). 8672/1: Pápateszér „Görgő-ér” J5 (KeveY 2015b: 64), „Mehetősi-erdő=Első-ér” J5 (KevEY 2015b: 64). 8672/2: Bakonyszentlászló „Pagonyierdő: Hódos-ér” J5 (KeveY 2015b: 64). - Fenyőfo „Halastói-patak” J5 (KeveY 2015b: 64). 8770/4: Kup „Kupi-erdő” J5 (K: 1989). B: 8771/2: Bakonyjákó-Iharkút „Sármás” J5 (K: 2015). 8773/2: Bakonynána „Római-fürdő” J5 (K: 1995). 8773/4: Olaszfalu „Puszta-berek” J5 (K: 1996). 8872/1: Herend „Molnártanya” J5 (K: 2008). Khg: 9169/2: Zalaszántó „Várberek” J5 (K: 1988). ÉZ: 9267/4: Zalaszentmihály „Sinkei-erdő” J5 (K: 2012). DZ: 9668/2: Iharosberény „Szentpáli-erdő” J5 (K: 1987). Zd: 9667/3: Ôrtilos „Visszafolyó-patak” J2, J5 (KeveY \& Toldi 2013: 54). BS: 9469/3: Zalakomár „Csöngő-kút” J5 (K: 1990). 9469/4: Szőkedencs „Csörgető” J5 (K: 1998). 9470/4: Marcali „Nagy-Gyóta” J5 (K: 1994). 9471/1: Csömend „Koszód” J5 (K: 1990). 9472/1: Somogyvár „Télizöld” J5 (K: 1998). 9569/1: Somogysimonyi „Gödörberki-erdő” J5 (K: 1998). 9570/2: Hosszúvíz „Színai-berek” J5 (K: 1995). - Mesztegnyő „Soponyai-tó” J5 (K: 1987), „Búsvár” J5 (K: 1992), „Dávodi-erdő erdőrezervátum” J5 (K: 1985), „Mélyégeri-halastó” J5 (K: 1993). 9570/4: Nagybajom „Lencsenpuszta és Szilibükk közöttt” J5 (K: 1992). - Böhönye-Dávodpuszta „Tranglus-erdő” J5 (K: 1993), „Halászház” J5 (K: 1995), „Halastói-erdő” J5 (K: 1993). 9571/3: Nagybajom „Fehér-tó” J5 (K: 1996), „Bükk” J5 (K: 1992), „Cseri-irtás=Felső-Csikotai-erdő” J5 (K: 1995). 9669/4: Somogyszob „Bükki-malom” J5 (K: 1998), „Rinya-erdő” J5 (K: 1984). 9769/4: Szenta "Kiskunovica” J5 (K: 1982). 9771/1: Nagykorpád „Mórici-erd”” J5 (K: 1985). Zs: 9673/3: Sántos „Herceg-forrás” J5 (K: 2010). 9773/1: Gálosfa „Vörösalma-erdő” J5 (K: 2016).

Cardamine enneaphyllos (L.) Crantz - B: 8674/4: Bakonycsernye „Kisgyóni-erdő” K5 (K: 2015). Khg: 9069/2: Csabrendek „Rendeki-hegy” K5 (K: 2006). 9069/4: Zalaszántó „Farkas-hegy” K5, LY2 (K: 1977). - Bazsi „Kőbánya” K5 (K: 2004). 9169/2: Lesenceistvánd „Kő-orra” K5, LY2 (Kevey \& Sonnevend ined.: 2014). 9169/4: Balatongyörök „Pad-kő-árok” K2, LY1 (K: 2003). - Lesencefalu „Nagy-domb” K2, K5 (K: 1987). - Vállus „Csetényi-erdő” K5, LY2 (K: 1987), „Barbacsi-erdő” K5 (K: 2000), „Miklós-völgy” K5, LY1, LY2 (K: 1985). 9170/3: Nemesvita „Sárkány-erdő” K5 (K: 1986). 9269/2: Balatongyörök „Kígyós-völgy” K2, K5 (K: 1986). - Gyenesdiás „Büdöskúti-völgy” K2, K5 (K: 1986). 9270/1: Balatonederics „Edericsi-hegy” LY2 (K: 1982). DZ: 9566/1: Zajk „Béci-hegy” K5 (K: 2005). BS: 9470/4: Marcali „Nagy-Gyóta” K1a, K5 (KeveY 2013a: 30). 9570/2: Hosszúvíz „Színai-berek” J5 (K: 1995). - Mesztegnyő „Dávodi-erdő erdőrezervátum” J5, K1a, K5 (KeveY 2013a: 30), „Búsvár” K1a (K: 1992), „Szili-bükk” K1a (K: 1991). 9570/4: Nagybajom „Cífratanya és Dávodi-tó között” J5, K1a (K: 1991). 9571/3: Nagybajom „Fehér-tó” J5, K5 (K: 1988). 9669/4: Somogyszob „Rinya-erdő: Kis-mező” K1a, K5 (KeveY 2013a: 30), „Rinya-erdő: Szénégető” K1a, K5 (KEvEY 2013a: 30), „Bükki-malom” J5, K1a, K5 (K: 1984). 9769/4: Szenta „Kiskunovica” J5 (K: 1982). 9771/1: Nagykorpád „Mórici-erdő” J5, K1a (KEVEY 2013a: 30). Zs: 9773/3: Bőszénfa „Pap-hegy” K5, LY1 (Kevey 2010: 39; Kevey 2013c: 35). 
9773/4: Gálosfa „Csepegő-kő” K5, LY1 (KeveY 2010: 39; KEveY 2013c: 35), „Sárközi-erdő” K5, LY1 (KeVEY 2010: 39; KeveY 2013c: 35). V: 9775/1: Kisvaszar „Bikági-völgy J5, K1a, K5 (K: 2009). Mcs: 9874/2: Husztót „Husztóti-völgy” K5 (K: 2014). - Magyarhertelend „Gödrihegy: a termálfürdő feletti erdőben” K2, K5 (KEvEY 2015d: 25). 9874/3: Hetvehely „Nyárasvölgy” J5, K5 (KEveY \& BARANYI 2002: 15), „Sás-völgy” J5, K1a (KEVEY \& BARANYI 2002: 15).

Cardamine flexuosa With. - BSzS: 7899/2: Gyüre „Palaj-szeg” J4 (Kevey 2015a: 48). Sajnos az idézett cikkemben tévesen 7901/1 raszterkód alatt közöltem az adatot. Így került be a flóraatlaszba (BARTHA et al. 2015: 105). Ennek térképén a 7901/1-es raszterből az előfordulás törlendő, helyette a 7899/2-es raszter az érvényes.

Carpesium abrotanoides L. - Dv: 9379/3: Paks-Dunakömlőd „Imsós-erdő” (KÁRPÁTI I. in KeVEY \& TóTH I. 2000: 138). Sk: 9878/2: Báta „Gyűrűs-alj” J4, J6 (KeVEY \& TóTH I. 2000: 138). Zd: 9767/1: Őrtilos „a vasútállomás melletti erdőszélen” (K: 1984). 1990 körül itt földmunkákat végeztek, azóta töbször is hiába kerestem! Gd: 9777/4: Mórágy „Henrikforrás völgyében" LY1 (KEVEY 2015a: 50).

Carpesium cernuum L. - Sk: 9579/1: Fadd „Várszegi-erdő” (MENYHÁRTh 1877: 98). 9679/3: Őcsény „Gemenc” (TótH I. 1958: 129). 9779/1: Decs (TóTH I. 1958: 129) „Szomfova” J6, K1a (KeveY in KeveY \& TótH I. 2000: 138). 9779/3: Decs „Keskeny-erdő” J6, K1a (TótH I. in KeveY \& TóTH I. 2000: 138), „Gyöngyös-oldal” J6, K1a (KeveY \& TóTH I. 2000: 138). - Baja „NagyRezét” J6, K1a (KeveY in KeveY \& TótH I. 2000: 138). Msz: 0078/3: Kölked „Felső-Béda” J6 (Kevey in Kevey \& Tóth I. 2000: 138). 0078/4: Kölked (Tóth I. 1958: 129) „Béda: a vadászháznál” J6 (BoRos in KevEY \& O.Kovács et al. 1992: 19), „Alsó-Béda” J6 (K: 2014). Homorúd "Árok-erdő" J6 (Tóth I. in KeveY \& O.KovÁcs et al. 1992: 19). Zs: 9673/3: Kaposvár „Vaskapu” LY1 (KEvEY 2010: 43, 2013c: 35). - Sántos „Herceg-forrás” LY1 (KEVEY 2010: 43, 2013c: 35). 9773/1: Kaposgyarmat „Tótfalusi-erdo”" (K: 2017). Th: 9277/3: Kisszékely „Hosszú-tisztás melletti erdőben” K1a, L2x (K: 2017).

Chaerophyllum aromaticum L. - Ny: 8100/3: Mérk „Vadaskerti-erdő” (Kevey \& Papp L. ined.: 2004).

Corydalis intermedia Link - Ba: 8572/4: Gic „Gerencséri-erdő” J5 (Kevey 2015b: 62). 8672/1: Fenyőfő „Mészkemence” L5 (KeveY 2013b: 72). - Pápateszér „Görgő-ér” J5, K1a (KEvEY 2015b: 62). B: 8671/4: Ugod „Közép-hegy” K2, K5 (K: 1998). 8672/2: Bakonyszentlászló „Cuha-völgy” LY1, LY2 (K: 1994). 8674/4: Bakonycsernye „Kisgyónierdő" K2, K5 (K: 2015). 8771/2: Bakonyjákó-Iharkút „Sármás” J5, K2, LY4 (K: 2015). 8771/4: Németbánya „Püspök-erdő” K2 (K: 1998). 8772/1: Bakonybél „Hideg-hegy” K5, LY2 (K: 1998), „Tönkölös” K2, K5, LY4 (K: 2015). 8772/3: Bakonybél „Kálvária” K1a, K2 (K: 1996). - Ugod „Pápa-vár” K2, K5 (K: 1996). - Bakonyjákó-Iharkút „Hajmás-sarok” K2 (K: 2016). 8773/2: Bakonynána „Haraszt-erdő” K2, K5 (K: 1995). 8773/4: Olaszfalu-Alsópere „a hajmáskéri út mellett” K2 (K: 1996), „Tunyog-hegy” K2, K5 (K: 2012). - Eplény „Ámoshegy” K2, K5, LY4 (K: 2012). 8774/2: Isztimér „Hárs-hegy” K2, K5 (K: 1996). 8774/4: Várpalota „Vár-völgy” K5, LY2 (K: 2013), „Pléhorgya-völgy” K5, LY2, LY4 (K: 2014). 8872/2: Márkó „Csordás-árok” K2, LY4 (K: 2014). 8872/4: Szentgál „Miklóspál-hegy” K2, K5, LY2, LY4 (K: 1998), „Mecsek-hegy” K2, K5, LY2, LY4 (K: 2007), „Bece-kő” K2, K5 (K: 2006), „Köveskúti-tetô” K2, K5, LY4 (K: 2006), „Balog-szeg” K2, K5, LY4 (K: 2007). 8873/1: Lókút „Papod” K2, K5, LY2, LY4 (K: 2009). - Veszprém-Gyulafirátót „Kis-Papod” K2, K5, LY2, LY4 (K: 2011), „Mohos-kő” K2, LY4 (K: 2011), „Gyökeres” K2, LY4 (K: 2016). - Hárskút „Esztergály-völgy” K2, K5, LY1, LY2, LY4 (K: 1998). 8972/2: Szentgál „Alsó-Zombor” K2, K5 (K: 2000), „Felső-Zombor” K2, K5 (K: 1998). - Nemesvámos „Hárs-hegy” K2, K5, LY4 (K: 2000). 8972/3: Úrkút „Vöröstói-tető” Ke, K5, LY4 (K: 2000).

Corydalis pumila Rchb. - Zm: 8577/3: Vértesboglár „Som-gödör” K1a, L2x (Kevey et al. 2015: 113). - Alcsút „Csaplári-erdő” K1a, L2x, M2 (KeveY et al. 2015: 113). 8577/4: Alcsút „Csaplári-erdő” K1a, L2x, M2 (KeveY et al. 2015: 113). 8676/4: Zámoly „Csapás-völgy” K1a, 
L2x, M2 (Kevey et al. 2015: 113). 8677/3: Lovasberény „Kastély-park” K1a, L2x (K: 2011). 8678/1: Vál „Váli-erdő” L2x (KeveY et al. 2015: 113). Ba: 8672/1: Fenyőfo „Kuruc-erdő” K1a (KeVEY 2014b: 61; KeVEY 2015f: 48), „Halastói-patak” J5 (KeVEY 2015b: 62). 8572/4: Gic „Gerencséri-erdő” J5 (KeveY 2015b: 62). 8770/4: Kup „Kupi-erdő” J5, K1a (K: 1989). B: 8671/4: Ugod „Somberek” K2, LY4 (K: 2015). 8672/2: Bakonyszentlászló „Cuha-völgy” LY2 (K: 1994), „Pagonyi-erdő: Hódos-ér” J5 (K: 2002). 8674/4: Bakonycsernye „Kisgyóni-erdő” K2 (K: 2015). 8771/2: Ugod „Durrogós” K2, K5 (K: 1996), „Szár-hegy” K2, K5 (K: 2015), „Közép-hegy” K2 (K: 2000). - Bakonyjákó-Iharkút „Sármás” K2, LY4 (K: 1996). 8873/4: Veszprém „Csatár-hegy” K2, LY4 (K: 1999). Mf: 8678/4: Martonvásár (KeVEY in PRISZTER 1980: 176) „Kastély-park” J6 (Kevey 1983: 21). 8879/3: Adony „Park-erdő” J6 (K: 1997). 9277/4: Vajta „Park-erdő” J6, K1a (Kevey B. \& LendvaI G. 2015: 22). 9377/2: Vajta „Nagyerdő” K1a, L5 (K: 1980). KS: 9475/2: Tamási „Likas-hegy” K1a (K: 1981). 9575/1,2: Döbrököz „Hajagos-erdő” K1a (K: 1994). Mcs: 9876/1: Hosszúhetény „Zengő” K5, LY2 (KEVEY 1988: 97). Gd: 9877/3: Geresdlak „Kisgeresdi-erdő” K2 (K: 2004).

Corydalis solida L. - R: 8568/1: Rábakecöl „Kapuszegi-erdő” K1a (K: 2005). 8668/2: Kenyeri „Nasici-erdő” K1a (K: 2004). Ny: 8496/4: Debrecen „Nagy-Cserei-erdő” J6 (KEVEY \& PAPP ined.: 2003). VRv: 8867/3: Rum „Rumi-erdő” J6, K1a (KEVEY 2015e: 226). Ba: 8770/4: Kup „Kupi-erdő” J5, K1a (K: 1989). 8871/1: Noszlop „Becsei-erdő” J5, K1a (K: 2002). Mm: 8868/4: Kemenespálfa „Martonfai-erdő” K1a (K: 2009). 8869/2: Kiscsősz „Nagy-erdő” K1a (K: 2009). Mf: 8976/4: Soponya-Nagyláng „Kastély-park” J6, K1a (Kevey 1983: 21). B: 9069/2: Csabrendek „Rendeki-hegy” K2, K5, LY2, LY4 (K: 2001). - Sümeg „Fehér-kövek” K2, K5 (K: 2005). Khg: 9169/4: Vállus „Csetényi-erdő” J6, K2, K5, LY2 (K: 1987), „Barbacsierdő” J5, K2, K5 (K: 1986). - Lesencefalu „Nagy-domb” K2, K5 (K: 1987), „Kis-Láz-tető” K2 (K: 1985), „Szent-Miklós-völgy” K2, K5, LY1, LY2 (K: 1985). 9269/2: Balatongyörök „Kígyós-völgy” K2, K5, LY2 (K: 1986). K: 8967/3: Csehi „Csehi-hegy” K1a (K: 1990). ÉZ: 9068/4: Vindornyaszőlős” „Felső-erdő” K1a (K: 1993). 9166/3: Böde „Bödei-völgy” LY1 (K: 2005). 9267/4: Zalaszentmihály „Sinkei-erdő” J5, J6 (K: 2012). DZ: 8567/2: Sormás „Kurucvágás” K1a (K: 2016). 9465/2: Tormafölde „Csokmai-erdő” K1a, K2, K5 (K: 2012). 9466/3: Bázakerettye „a temető melletti erdőben” K2, K5 (K: 2009). 9466/3: Kiscsehi „Pityerdomb” K2, K5 (K: 2009). 9466/3: Kistolmács „Bömbölés” K2, K5 (K: 2009). 9467/1: Bucsuta „Börzöncei-hegy” K2, K5 (K: 2009). 9467/3: Eszteregnye-Obornak „Márki-erdő” K2, K5, LY1 (K: 1986). - Homokkomárom „Aligvári-hegy” K2, K5 (K: 2013). 9467/3: Oltárc „Gurgó-hegy” K2, K5 (K: 2008). 9467/4: Hosszúvölgy „Alsózsigárdi-erdő” J6, K1a (K: 2015). 9468/2: Zalakaros „Kanica-erdő” K2, K5, LY1 (K: 2005). 9468/4: Zalakaros „Szőlő-hegy” K2, K5 (K: 1991). 9566/2: Valkonya „Valkonyai-erdő: a becsehelyi műút mellett” K2, K5 (K: 2008). 9566/3: Letenye „Júlián-hegy” K2, K5 (K: 2008). 9567/1: Rigyác „Szuloki-erdő” K2, K5 (K: 2008). 9568/2: Nagyrécse „Virág-hegy” J5, K2, K5 (K: 1974). BS: 9471/3: Libickozma „Kopári-erdő” K1a (KeveY 2013a: 29). 9570/2: Hosszúvíz „Színai-berek” J5, K1a (KevEY 2013a: 29). 9571/1: Mesztegnyő „Soponyai-tó és Szili-Bükk között” J5, K1a (K: 1991). 9669/4: Somogyszob „Bükki-malom” J5, K1a, K5 (K: 1984), „Kővölgyi-erdő” J5, K1a, K5 (Kevey 2013a: 29). 9769/4: Nagyatád „Döbrögi-erdő” K1a (Kevey 2013a: 29). 9770/3: Nagyatád „Simongáti-erdő” K1a (K: 1990). 9771/3: Mike „Patkány-domb” J5, K1a (K: 1996). KS: 9472/1: Somogyvár „Télizöld” J5, K2 (K: 1998). Vlhg: 0175/2: Bisse „Pécsilapis” K1a, K2 (Kevey 2016: 36), „Remete” (KeVEY 1987a: 1. táblázat).

Cyclamen purpurascens Mill. - Mf: 8678/4: Martonvásár „Kastély-park” J6 (KeveY et al. 2016: 282, Table S2). Bizonnyal ültetve! 8976/4: Soponya-Nagyláng „Kastély-park” K1a (HANGAY 1889: 159; KEvEY 1988: 98). Bizonnyal ültetve! 8977/2: Sárosd „Kastély-park” K1a (K: 1998). Bizonnyal ültetve! 9176/2: Dég „Kastély-park: Ördög-domb” K1a (KEVEY 1984: 53). Bizonnyal ültetve! Khg: 9169/4: Vállus „Barbacsi-erdő” K2, K5 (K: 2002). DZ: 9367/1: Söjtör „Fúró-hegy” K5, LY1 (K: 1985). 9466/1: Lasztonya „Borshely-árok” LY1 (KEVEY 
2008a: 44/4. táblázat). 9468/1: Újudvar „Csibiti-völgy” K2, K5, LY1 (KeveY 2008a: 44/4. táblázat). - Nagybakónak „Tukora” LY1 (KEVEY 2008a: 44/4. táblázat). 9468/3: Újudvar „Dalasi-oldal” K5 (K: 2006). 9468/2: Zalakaros „Kanica-erdo”” K2, K5, LY1 (KeveY 2008a: 44/4. táblázat). 9468/4: Zalakaros „Szőlő-hegy” K2, K5, LY1 (K: 1991). 9566/1: ZajkJózsefhegy „a Béci-patak melletti erdőben” K2, K5 (K: 2009). 9566/2: Valkonya „a becsehelyi műút melletti erdőben” K2, K5 (K: 2008). 9667/2: Miklósfa „Szaplányosi-erdő” K1a, K2 (K: 1987). 9668/2: Iharosberény „Szentpáli-erdő” K2, K5 (K: 1988). 9668/4: Iharos-Ágneslak „Gágyi-erdő” K2, K5 (K: 2012). BS: 9571/1: Mesztegny”̋ „Felső-Kak” K1a, K5 (KeveY 2013a: 29). 9669/4: Somogyszob „Kővölgyi-erdő” K1a, K5 (KeveY 2013a: 29), „Bükki-malom” J5, K1a, K5 (Kevey 2013a: 29), „Rinya-erdő: Kis-mező” K1a, K5 (KeveY 2013a: 29), „Rinya-erdő: Szénégető” J5, K1a (Kevey 2013a: 29). KS: 9471/2: Somogyvár „Kastély-erdő=Brézai-erdő” K2 (K: 1997). Zs: 9672/3: Szenna „Derék-hegy” K2 (Juhász ex verb.: 2007). 9772/1: Bárdudvarnok-Lipótfa "Cseberki-erdő” K2 (Pintér ex verb.: 1989). Mcs: 9874/3: Bakonya „Sás-völgy” K2 (KEveY 1990: 89).

Doronicum hungaricum (Sadl.) Rchb. - DTk: 8782/2: Csévharaszt „Pótharaszti-erdő” K1a, L5 (K: 2015). Zm: 8676/4: Zámoly „Csapás-völgy” L2x, M2 (KEVEY \& LENDVAI in KeveY et al. 2015: 118). Mf: 9377/2: Vajta „Nagy-erdő” L5 (Kevey 2015c: 24). Vehg: 8777/3: Pákozd „Somos-völgy” K2 (Kevey \& Simon in KeveY et al. 2014: 235). Mcs: 9875/3: Pécs „Kis-Tubes” LY4 (KEVEY in KEVEY \& BoRHIDI 2010: 210), „Nagy-Tubes” LY4 (K: 2016), „Lapis: Tolvajgödör” LY4 (KeVEY in KeVEY \& BoRHidi 2010: 210), „Lapis: Sós-hegy” LY4 (KEVEY in KevEY \& BORHIDI 2010: 210), jelenleg is élő előfordulások. Vlhg: 0175/2: Harkány „Tenkes-sarok” L2a (Kevey 2012b: 49). - Máriagyüd "Csukma-hegy” L1, L2a, (Kevey 2012b: 49).

Doronicum orientale Hoffm. - Mcs: 9776/3: Magyaregregy „Máré-vár” L2a (Tóth I. Zs. ex litt:: 2011). 9875/2: Komló „Fehér-part” K2, L2a (Tóth I. Zs. ex litt.: 2015).

Echium italicum L. - KS: 9371/1: Buzsák „Csisztapuszta” H4 (K: 2016).

Eranthis hyemalis (L.) Salisb. - Mf: 8678/4: Martonvásár „Kastély-park” (LeHEL in KeveY 1990: 86). 8976/4: Soponya-Nagyláng (HANGAY 1889: 155) „Fácános-erdő” J6 (Horvát A. 0. \& Kevey ined.: 1974), „Kastély-park” J6, K1a (K: 1981). 9076/2: Káloz „Belmajor” J6 (KEveY 1990: 86). A: 8566/2: Sopronhorpács „Kastély-park” J6 (Kevey 1981: 180). Valamennyi helyen bizonnyal ültetve!

Galeobdolon luteum Huds. - Sz: 8169/2: Mosonmagyaróvár „Lóvári-erdő” J6 (KevEY 1990: 88). Mm: 9069/1: Zalagyömörő „Nyírlaki-erdő” J6 (K: 2012). R: 8668/1: Uraiújfalu „Kőrétierdő" K1a (Kevey \& Barna ined.: 2014). 8668/2: Kenyeri „Nasici-erdő” K1a (K: 2004). VRv: 8867/3: Rum „Rumi-erdő” J6, K1a (KeveY 2015e: 226). - Zsennye „Zsennyei-erdő” J6 (K: 2016). 8965/3: Kemestaródfa „Bagólé-erdő” J6, K1a (Kevey 2015e: 226). - Körmend „Dobogó-erdő” K1a (KeVEY 2015e: 226). Má: 9565/2: Szemenyecsörnye „Cserneci-holtág” J6 (KeVEY in KeVEY \& KovÁCs 2010: 212), „Cserneci kavicsbánya melletti erdő” J6, K1a (KEvEY in KEvEY \& KovÁcs 2011: 222). SDs: 9768/1: Porrogszentkirály „Fetec-erdő” J6, K1a (KEvEY 2007a: 91). 9768/4: Berzence-Perdócmajor „Park-erdő” J6 (K: 1981). - Csurgó „Lankócierdő" J5, J6, K1a (KeveY 2007a: 91). 9869/3: Somogyudvarhely „Almási-erdő” J6, K1a (KeveY 2007a: 91). - Bélavár „Bereki-erdő” J6, K1a (KeveY 2007a: 91), „Palinai-erdő” K1a (KeveY 2007a: 91). BDs: 0174/1: Vajszló „Bükk-hát” J6, K1a (K: 2007b: 48). Zm: 8576/4: Csákvár „Kastély-park” J6, K1a (K: 2011). 8875/4: Nádasdladány „Kastély-park” J6 (KEVEY 2001a: 98). Mf: 8678/4: Martonvásár „Park-erdő” J6, K1a (KEVEY 1981: 180). 8976/4: Soponya-Nagyláng „Park-erdő” J6, K1a (KeVEY 1985a: 156). 9478/1: Kajdacs „Kiskajdacsierdő" J5, J6, K1a (Kevey \& Lendvai ined.: 2007). 9578/1: Szedres „József-erdő" J6 (K: 2002). Cssz: 8780/1: Szigethalom „Tököli-erdő” J6 (K: 1993). 8879/1: Ráckeve „Besnyő” J6 (KEvEY 1993a: 56 „Schilling-erdő” néven). J: 8383/1: Verseg-Fenyőharaszt „Park-erdő” J6 (KEvEY 1981: 180). DTk: 8584/3: Szentmártonkáta „Kastély-park” K1a (K: 2014). 8781/1: Ócsa (JÁRAI-Komlódi 1958: Tabelle IX.), „ómér-erdő” J5, J6 (K: 2015). Ny: 8299/2: Bátorliget 
„Veres-folyás” J6, K1a (K: 1982). Bk: 7698/3: Révleányvár „Pap-erdő” J6, K1a (K: 2008). BSzS: 7800/1: Vámosatya „Bockereki-erdő” J6, K1a (K: 2009). 7801/1: Beregdaróc „Csereerdő" K1a (K: 2009). 7801/3: Tarpa „Téb-erdő” J6, K1a (K: 2003). 7801/4: Tarpa „Nagyerdő" J6, K1a (K: 2003). B: 8771/2: Bakonyjákó-Iharkút „Sármás” J5, K2 (K: 2015). 8672/2: Bakonyszentlászló „Cuha-völgy” LY1, LY2 (K: 1994). 8672/4: Fenyőfő „Kőris-hegy” K5 (K: 1996). 9772/1: Bakonybél „Hideg-hegy” K5, LY2 (K: 1998), „Gerence-völgy” J5, K5, LY1, LY2 (K: 2010). Ba: 8871/3: Devecser „Beréndi-erdo”” J5, J6, K1a (K: 2005). 8672/1: Pápateszér „Görgő-ér” J6, K1a (KeveY 2014b: 60; KEVEY 2015f: 48; KeVEY 2015b: 62). Khg: 9169/2: Lesenceistvánd „Kő-orra” K2, LY2 (K: 2014), „Uzsa-Hubertusz” J5, J6, K1a (K: 1993). 9169/4: Vállus „Szentmiklós-völgy” K2, K5, LY1, LY2 (K: 1985), „Csetényi-erdő” J6, K5, LY1, LY2 (K: 1987). 9269/2: Balatongyörök „Kígyós-völgy” K2, K5, LY2 (K: 1986). A: 8665/4: Gencsapáti „Aponyi-park” J6, K1a (K: 1998). ÉZ: 9167/1: Zalaszentiván „Kisfaludihegy” K2, K5 (K: 1976). DZ: 9468/1: Újudvar „Csibiti-völgy” K2, K5, LY1 (K: 2008a: 44/4. táblázat). - Nagybakónak „Tukora” LY1 (K: 2008a: 44/4. táblázat). 9468/3: Újudvar „Dalasi-oldal” K5 (K: 2006). 9668/1,3: Liszó „Medvés” K2, K5 (K: 1987). 9668/2: Iharosberény „Szentpáli-erdő” J6, K2, K5 (K: 1987). 9668/4: Csurgónagymarton-Ágneslak „Gágyi-erdő" K2, K5 (K: 2012). BS: 9469/3: Zalakomár-Ormándpuszta „Csöngő-kút” J5, J6 (K: 1989). 9470/4: Marcali „Nagy-Gyóta” K1a, K5 (KeveY 2013a: 28). 9569/1: Somogysimonyi „Gödörberki-erdő” J5, J6, K1a (K: 1998). 9571/3: Nagybajom „KözépsőKak=Fehér-tó” J6, K1a (KevEY in KevEY et al. 1998: 250), „Felső-Csikotai-erdő” J5, K1a, K5 (KeveY in KeveY et al. 1998: 250), „Bükk” K1a, K5 (KeveY in KeveY et al. 1998: 250). 9669/4: Somogyszob „Kővölgyi-erdő” J5, K1a, K5 (KevEY in Kevey et al. 1998: 250), „Bükki-őrház” J6, K1a, K5 (KeVEY in KeveY et al. 1998: 250), „Rinya-erdő: Kis-mező” K1a, K5 (KeveY in KeveY et al. 1998: 250), „Rinya-erdő: Szénégető” K1a, K5 (KevEY in KeVEY et al. 1998: 250). 9769/4: Nagyatád „Döbrögi-erdő" K1a (KEVEY 2013a: 28). 9769/4: Szenta „Kiskunovica” J5 (K: 1982). 9770/4: Nagyatád „Ámor-erdő” J6 (K: 1984). 9869/3: Bélavár „Kerék-hegy” K1a, K5 (KeveY in KeveY et al. 1998: 250). 9870/1: Nagyatád „Simongáti-erdő” J6, K1a (K: 1989). Rinyaszentkirály „Ág-erdő” J5, J6 (K: 1997), „Polai-erdő” J6, K1a (Kevey 2013a: 28). 9970/3: Babócsa „Vár-domb” J6, K1a (K: 1980). KS: 9471/2: Somogyvár „Park-erdő” K2 (K: 1997). 9472/1: Somogyvár „Télitöld” J6, K2 (K: 1997). Zs: 9673/1: Kaposvár „Nádasdierdő” J5, K1a, K2, K5 (K: 1981). 9772/2: Bőszénfa „Ropoly” K2, K5, LY1 (K: 2015). 9773/3: Bőszénfa „Farkaslak” K2, K5 (Horvát A. 0. \& Kevey ined.: 1974), „Pap-hegy” K2, K5, LY1 (Horvát A. 0. \& Kevey ined.: 1974). - Almamellék „Sas-rét” J5, K2, K5 (K: 2011), „Terecsényi-erdő” K2, K5 (K: 2011). V: 9575/4: Kurd „Szentkúti-erdő” J6, K1a (K: 2012). Vlhg: 0176/2: Villánykövesd „Fekete-hegy” K2, K5, LY2, LY4 (KeVEY 2016: 35). Nagyharsány „Ördög-árok” K1a, K2 (KeveY 2016: 35), „Vár-erdő” K2, K5, LY2, LY4 (KEVEY 2016: 35). Bd: 9975/3: Kökény „Malom-völgy” K2 (K: 1994). Szd: 9678/3: Szekszárd „Gurovica” K2 (K: 1990). 9778/1: Szálka „Rácz-erdő” J5, K2 (K: 1990).

Helleborus dumetorum Waldst. et Kit. - Mf: 8678/4: Martonvásár „Park-erdő” J5 (Boros in KEVEY 1983: 20; Kevey, Majláth \& Molnár ined.: 2012), „Gábormajori-erdő” J6 (K: 1997). A „Park-erdő”-ben talán ültetve, de utóbbi helyen őshonosnak látszik! 8877/4: Seregélyes „Kastély-park” J6 (K: 1997). Talán ültetve! 8976/4: Soponya-Nagyláng „Kastély-park” J6, K1a (Kevey 1983: 20). Valószínűleg ültetve! 9176/2: Dég „Park-erdő” J6 (Kevey 1981: 180). Talán ültetve, bár a közeli hunyoros dülő az őshonosságát sejteti! B: 8873/2: VeszprémGyulafirátót „Gyökeres” K2, L2a (K: 2016). Zd: 9667/3: Őrtilos „Szentmihály-hegy” J6 (KevEY 1985a: 155). KS: 9475/4: Gyulaj "Garasházi-erdo”" K1a (Horvát A. O. \& Kevey ined.: 1981). BS: 9768/3: Somogyudvarhely „Zdálai-erdő=Vecsenye” J6 (KEVEY 1985a: 155).

Helleborus odorus Waldst. et Kit. - BDs: 9973/2: Kacsóta „Felső-erdő” K1a (BORHIDI \& KEVEY in KeveY 1995: 46). Mf: 8976/4: Soponya-Nagyláng „Park-erdő” J6, K1a (KeveY 1983: 20). 
KEVEY (2017): Pótlások Magyarország edényes növényfajainak elterjedési atlaszához IV.

Valószínúleg ültetve! Zs: 9774/1: Baranyajenő „Öreg-hegy” K2 (K: 2000). 9774/3: Palé „Öreg-hegy” K2 (KEVEY 1993a: 55).

Hepatica nobilis Schreb. - Mf: 8976/4: Soponya-Nagyláng „Park-erdő” J6, K1a (KevEY 1985a: 155). Valószínúleg ültetve! B: 8771/2: Bakonyjákó-Iharkút „Sármás” K2 (K: 2015). Khg: 9169/1: Rezi „Hosszú-hegy” K2, LY2, LY4 (K: 1984), „Púpos-hegy” K2, K5, LY2, LY4 (K: 1984). 9170/3: Nemesvita „Sárkány-erdő” K2, K5 (K: 1986). A: 8566/2: Sopronhorpács „Kastély-park” J6 (K: 1979). Talán ültetve! DZ: 9568/2: Nagyrécse „Virág-hegy” J5, K2, K5 (K: 1978). BS: 9471/3: Libickozma „Kopári-erdő” K1a (KeVEY 2013a: 29). 9570/2: Hosszúvíz „Színai-berek” J5, J6 (Kevey 2013a: 29), „Jegyző-irtás” J5, J6 (Kevey 2013a: 29). 9570/2: Mesztegnyő „Búsvár” J5, K1a (KeveY 2013a: 29). 9570/2: Mesztegnyo „Mélyégerihalastó” J5, K1a (K: 1993). 9571/1: Mesztegnyő „Felső-Kak” J5, K1a, K5 (KEVEY 2013a: 29). 9571/3: Nagybajom „Fehér-tó” J6, K1a, K5 (K: 1988). 9571/3: Nagybajom „Felső-Csikotaierdő” J6, K1a, K5 (KeVEY 2013a: 29). 9771/1: Nagykorpád „Mórici-erdő” J5, K1a (KEveY 2013a: 29). KS: 9472/1: Somogyvár „Télizöld” J5, K1a (K: 1998).

Hesperis sylvestris Crantz - Mcs: 9875/1: Magyarszék „Rauch-Berg” (Havasi ined.: 2016). 9874/4: Pécs „Vörös-hegy” L1 (K: 1976).

Hieracium umbellatum L. - Tt: 8391/4: Egyek „Ohat-erdő” L5 (K: 2016). Csak pár m²-en egyetlen populáció. MÁTHÉ (1933: 175) adata megerősítést nyert.

Isopyrum thalictroides L. - BSzS: 7701/3: Beregdaróc „Dédai-erdő” K1a, K5 (K: 2003). 7801/3, 7801/4: Tarpa „Nagy-erdő” J6, K1a (K: 2003). 7903/1: Magosliget „Fischer-erdő” J6, K1a (K: 2003). 8002/2: Túrricse „Ricsei-erdő” J6, K1a (K: 2010). Mm: 8770/1: Dáka „Tilos-erdő” K1a (K: 2010). 8870/1: Doba „Felső-erdő” K1a (K: 2003). VRv: 8965/3: Körmend-Horvátnádalja „Dobogó-erdő” K1a (KeveY 2015e: 227). Mf: 8976/4: SoponyaNagyláng „Park-erdő J6, K1a (Kevey 1983: 20). SDs: 9768/3: Somogyudvarhely „Zdálaierdő=Vecsenye” J6, K1a (KevEY 1985a: 155). 9971/4: Kisdobsza „Kisdobszai-erdő" J6, K1a (UHERKovich Á. in KeveY 1983: 20). Khg: 9169/1: Rezi „Hosszú-hegy” K2, LY2, LY4 (K: 1984). 9169/4: Vállus „Csetényi-erdő” K2, K5, LY1, LY2 (K: 1987). Ba: 8672/1: Pápateszér „Görgő-ér” J5, K1a (KeveY 2015b: 62). B: 8672/2: Bakonyszentlászló „Cuha-völgy” LY1, LY2 (K: 1994). 8672/3: Ugod-Huszárokelőpuszta „Gerence-völgy” J5, K5, LY1, LY2 (K: 1983). 8674/4: Bakonycsernye „Kisgyóni-erdő” K2, K5 (K: 2015). 8771/4: Bakonyjákó „Bittvapatak” J5 (K: 2015). 8772/1: Bakonybél „Gerence-völgy” J5, K5, LY1, LY2 (K: 1983). ÉZ: 9167/1: Zalaszentiván „Kisfaludi-hegy” K2, K5 (KEvEY 1993a: 55). 9168/3: Nagykapornak „Vecei-erdő" K2 (KeveY 1993a: 55). DZ: 9667/2: Miklósfa „Szaplányosi-erdő” J6, K2 (KEvEY 1993a: 55). BS: 9469/3: Zalakomár-Ormándpuszta „Csöngő-kút” J5, J6 (K: 1989). 9470/4: Marcali „Nagy-Gyóta” K1a, K5 (KeveY 2013a: 30), „Kis-Gyóta” J6, K1a (K: 1997). 9471/3: Libickozma „Kopári-erdő” K1a (KeveY 2013a: 30). 9569/1: Somogysimonyi „Gödörberkierdő” J5, J6, K1a (K: 1998). 9570/2: Hosszúvíz „Színai-berek” J5, J6 (KeVEY 2013a: 30). Mesztegnyő „Búsvár” J5, K1a (KEvEY 2013a: 30), „Dávodi-erdő erdőrezervátum” J5, K1a, K5 (KeveY 1990: 86). 9571/1: Mesztegnyő „Felső-Kak” J5, K1a, K5 (KeVEY 2013a: 30). Nagybajom „Középső-Kak” J6, K1a (KevEY 2013a: 30). 9771/1: Nagykorpád „Mórici-erdő” J5, K1a (KeveY 1990: 86). 9871/2: Kőkút „Babancsik” J5, J6 (K: 1996). KS: 9472/1: Somogyvár „Télizöld” J5, K2 (K: 1998). 9475/2: Tamási „Likas-hegy” K1a (K: 1981). Mcs: 9874/2: Husztót „Husztóti-völgy” J5, K1a, K5 (K: 2014). 9874/3: Hetvehely „Sás-völgy” J5, K1a, K2 (KeVEY \& BARANYI 2002: 15). Vlhg: 0175/1: Csarnóta „Kopasz-hegy” K2 (KEveY 2016: 36). 0175/2: Bisse „Remete” K2, K5, LY1 (KeVEY 2016: 36), „Pécsi-lapis” K1a, K2, K5 (KeveY 2016: 36), „Poszhagymás” K1a, K2, K5 (Kevey 2016: 36). - Kistótfalu „Kopasz-hát” K1a, K2, K5 (Kevey 2016: 36), „Csicsó-hegy” K2, K5 (Kevey 2016: 36). 0176/1: Vokány „Trinitás-erdő” J6, K1a, K2 (KEVEY 2016: 36). - Nagytótfalu „Császár-hegy” K2, LY1, LY2 (KeveY 2016: 36), „Kecskeháti-erdő” K2, L2a (Kevey 2016: 36). - Palkonya „Luca-karéj” K2, 
L2a (Kevey 2016: 36). Bd: 0076/3: Újpetre „Palkonyai-erdő” K1a (K: 2005). 9975/3: Kökény „Malom-völgy” K2 (K: 1994). Szd: 9678/3: Szekszárd „Gurovica” K2 (K: 1989).

Lathyrus lacteus (M. Bieb.) Wissjul. - Mcs: 9875/1: Pécs „Tubes” L1 (K: 1990). Th: 9277/3: Pálfa „Gyertyános” L2x (Kevey \& Lendvai ined.: 2010). 9377/1: Kisszékely „Kis-erdő” L2x (Kevey \& Lendvai ined.: 2010).

Lathyrus venetus (Mill.) Wohlf. - B: 8771/4: Farkasgyepű „Püspöki-erdő” K2 (K: 1998). 8772/1: Bakonybél „Hideg-hegy” K2 (K: 1998), „Kálvária” K1a (K: 2008). Khg: 9169/1: Rezi „Púpos-hegy” K2, K5 (K: 1984), „Vár-hegy” K2, K5 (K: 1984), „Hosszú-hegy” K2, LY4 (K: 1984), „Hosszú-völgy” K2, K5, LY1, LY2 (K: 1984). 9169/2: Lesenceistvánd „Kü-orra” K2, LY2 (K: 2014). 9169/4: Vállus „Barbacsi-erdő” K2, K5 (K: 1986), „Szentmiklós-völgy” K2, K5, LY1, LY2 (K: 1985), „Kis-Láz-tető” K2 (K: 1985). 9170/3: Lesencefalu „Somos-tető” K2 (K: 1987). 9270/1: Balatonederics „Edericsi-hegy” LY2 (K: 1982). DZ: 9465/2: Tormafölde „Csokmai-erdő” K2, K5 (K: 2012), „Vétyemi-erdő-Angyalirta-árok” K5, LY1 (KeveY 2008a: 44/7. táblázat). 9466/3: Kistolmács „Bömbölés” K2, K5 (K: 2009). 9468/1: Újudvar "Csibiti-völgy” K2, K5, LY1 (Kevey 2008a: 44/7. táblázat). 9566/2: Valkonya „Csákány-hegy” K2, K5 (K: 2008). Zs: 9673/3: Cserénfa „Tábor-völgy” K2, K5 (K: 1975). Kaposvár „Nádasdi-erdő” K2, K5 (K: 1975), „Vas-kapu” K2, K5, LY1 (KeveY 2010: 41; KeVEY 2013c: 35). 9674/2: Dombóvár „Szőlő-hegy” K2 (K: 1994). 9674/3: Nagyberki „Vadas-kert” K2 (K: 2013). - Szabadi „Szörnyű-gödör” K2 (K: 2012). 9772/1: Bárdudvarnok-Lipótfa „Dennai-erdő” K2 (K: 2009). 9774/1: Baranyajenő „Öreg-hegy” K2, K5 K: 2000), „Kósagödör” K2, K5 (K: 1996). 9774/3: Mindszentgodisa „Templom-völgy” K2 (K: 2013), „Livinca” K2 (K: 2013). - Palé „Nagy-hegy” K2 (K: 1989). V: 9775/1: Kisvaszar „Hosszúerdő” K2 (K: 2004), „Pósa-hegy” K2 (K: 2009), „Bikági-völgy” K2 (K: 1982). 9775/3: Kisvaszar „Bikági-völgy” K2, K5 (K: 1982). 9775/2: Ág „Vágyom-völgy” K2 (K: 1997). Mcs: 9874/3: Bakonya „Sás-völgy” K2 (K: 1978). 9875/4: Pécs-Vasas „Galambos” J5, K2 (K: 1998), „Vasasi-árok” J5, K2 (K: 1978). Vlhg: 0075/3: Turony „Sziget” K2 (K: 2010). 0076/3: Vokány „Trinitás-erdő” K2 (KeveY 2016: 38). 0174/2: Diósviszló „Csikorgó” K2 (K: 1989). 0175/1: Turony „Sziget” K2 (K: 2010). 0175/2: Bisse „Pécsi-lapis” K2, K5 (Kevey 1987a: 1. táblázat), „Remete” K2, K5 (Kevey 1987a: 1. táblázat), „Poszhagymás” K2, K5 (KeveY 1987a: 1. táblázat). - Kistótfalu „Kopaszhát=Átai-hegy” K2 (KeveY 1985b: 27), „Csicsó-hegy” K2 (KeVEY 1987a: 1. táblázat). 0176/3: Vokány „Trinitás-erdő” J6, K2 (Kevey 2016: 38).

Lunaria rediviva L. - Mf: 8678/4: Martonvásár „Park-erdő” J6 (KevEY 1983: 21). Talán ültetve!

Mercurialis perennis L. - Mm: 8869/4: Apácatorna „Galsai-erdő” J6, K1a (K: 2013). Mf: 8678/4: Martonvásár „Kastély-park” J6 (HoRvÁT \& KevEY in KeVEY 1981: 180). DTk: 9081/2: Kunadacs „Birkajárási-Új-erdő” K1a (KeveY 2015a: 45). BSzS: 7701/3: Beregdaróc „Közös-erdő” K1a (K: 2009). Ba: 8672/1: Pápateszér „Görgő-ér” J5, K1a (KEVEY 2014b: 60; KEvEY 2015f: 48). Khg: 9169/2: Lesenceistvánd „Kű-orra” K2, LY2 (K: 2014). - Zalaszántó „Tinóhálás” K1a (K: 2006), „Vár-berek” J6, K1a (K: 2006). 9169/3: Cserszegtomaj „Csókakő" LY1, LY2 (K: 1999). 9269/2: Balatongyörök „Kígyós-völgy” K2, K5, LY2 (K: 1986). Gyenesdiás „Büdöskúti-völgy” K2, K5, LY2 (K: 1986). 9270/1: Balatonederics „Edericsihegy” LY2 (K: 1982). ÉZ: 9068/4: Vindornyaszőlős „Felső-erdő” K1a (K: 1993). 9168/1: Kallosd „Kaponya” J5, K2, K5 (Kevey 1981: 180). - Gyürűs „Kígyós” K2 (KeveY 1981: 180). DZ: 9465/2: Páka-Dömefölde „Fejérlakosai-erdő” LY1 (KeVEY 2008a: 44/5. táblázat). Tormafölde "Vétyemi-erdő: Angyalirta-árok” K5, LY1 (KeVEY 2008a: 44/5. táblázat). 9466/1: Lasztonya „Cigány-árok” LY1 (KEvEY 2008a: 44/5. táblázat). - Lispeszentadorján „Diós-völgy” LY1 (KEvEY 2008a: 44/5. táblázat). 9467/1: Bucsuta „Börzöncei-hegy” K2, K5 (K: 2009). 9468/1: Nagybakónak „Tukora” LY1 (KeVEY 2008a: 44/5. táblázat). - Újudvar "Csibiti-völgy” K2, K5, LY1 (KeveY 2008a: 44/5. táblázat). 9566/1: Letenye „Csitári-erdő” K2, LY1 (KeveY 2008a: 44/5. táblázat). - Murarátka „Rátkai-hegy” K2, K5 (K: 2012). 
9568/2: Nagyrécse „Virág-hegy” J5, K2, K5 (K: 1978). 9667/2: Miklósfa „Szaplányosi-erdő” J6, K2 (K: 1987). BS: 9469/3: Zalakomár-Ormándpuszta „Csöngő-kút” J5, J6 (K: 1988). 9469/4: Szőkedencs „Csörgető” J6, K1a (K: 1998). 9470/4: Marcali „Nagy-Gyóta” K1a, K5 (KeVEY 2013a: 28). 9471/3: Libickozma „Kopári-erdő” K1a (Kevey 2013a: 28). 9569/1: Galambok „Vincédi-erdő” J6, K1a (K: 2014). - Somogysimonyi „Gödörberki-erdő” J5, J6, K1a (K: 1998). 9570/2: Hosszúvíz „Színai-berek” J5, J6 (K: 1995). - Mesztegnyő „Búsvár” J5, K1a (KeveY 2013a: 28), „Dávodi-erdő erdőrezervátum” J5, K1a, K5 (KeveY 2013a: 28). 9571/3: Nagybajom „Fehér-tó” J6, K1a (K: 1995). 9769/4: Szenta „Kiskunovica” J5 (KeveY 1981: 180). 9771/1: Nagykorpád "Mórici-erdő" J5, K1a (KEvEY 2013a: 28). 9870/1: Rinyaszentkirály „Ág-erdő” J5, J6 (K: 1997), „Polai-erdő” J6, K1a (KeveY 2013a: 28). V: 9575/4: Kurd „Szentkúti-erdő” J6, K1a (K: 2012). Bd: 9975/3: Kökény „Malom-völgy” K2 (K: 1994). Th: 9377/1: Nagyszékely „Kalános-erdő” K1a (K: 2014). - Kisszékely „Dukaivölgy” K1a (K: 2014), „Kis-erdő” K1a (K: 2011).

Orobanche purpurea Jacq. - Mcs: 9776/2: Váralja „Péró” M8 (K: 2016). 9875/1: Magyarszék „Németszéki-szőlőhegy” OF (Leg.: HavasI: 2016; Det.: Kevey: 2016). Bd: 9975/2: Pécs „Üszögpuszta” OF (Leg.: HAVASI: 2014; Det.: KeVEY: 2014).

Orobanche ramosa L. - Zs: 9774/2: Sásd „Német-domb" OF (Leg.: HAVASI: 2014; Det.: KevEY: 2014).

Oxalis acetosella L. - Ba: 8672/1: Pápateszér „Görgő-ér” J5, K1a (KeveY 2015b: 62), „Mehetősi-erdő" J5 (Kevey 2015b: 62). B: 8773/2: Bakonynána „Római-fürdő” J5, LY1 (K: 1995). 8774/2: Isztimér „Burok-völgy” LY1 (K: 2013), „Bükkös-árok” K5, LY1 (K: 2013). Khg: 9169/2: Zalaszántó „Vár-berek” J5, J6, K1a (K: 1988). 9169/4: Vállus „Csetényi-erdo”” J6, K1a, LY1 (K: 1985), „Szent-Miklós-völgy” LY1 (K: 1985). VRv: 8965/3: Kemestaródfa „Bagólé-erdő" J6, K1a (KEvEY 2015e: 228). Má: 9667/1: Murakeresztúr „Gyurgyánc” J6, K1a (KEVEY in KEVEY \& KovÁCS 2010: 212). SDs: 9768/3: Gyékényes „Lankóci-erdő” K1a (KEVEY 2007a: 92). 9869/1: Somogyudvarhely „Vecsenye” K1a (KeVEY 2007a: 92). DZ: 9468/2: Zalakaros „Kanica-erdő” K5, LY1 (K: 2008a: 44/5. táblázat). BS: 9469/3: ZalakomárOrmándpuszta „Csöngő-kút” J5, J6 (K: 1988). 9469/4: Szőkedencs „Csörgető” J6, K1a (K: 1998). 9470/4: Marcali „Nagy-Gyóta” K1a, K5 (Kevey 2013a: 30). 9471/3: Libickozma „Kopári-erdő" K1a (KeveY 2013a: 30). 9569/1: Galambok „Vincédi-erdő” J6, K1a (K: 2014). - Somogysimonyi „Gödörberki-erdő” J5, J6, K1a (K: 1998). 9570/2: Hosszúvíz „Színaiberek” J5, J6 (K: 1995). - Mesztegnyő „Búsvár” J5, K1a (KEvEY 2013a: 30), „Dávodi-erdő erdőrezervátum” J5, K1a, K5 (KEvEY 2013a: 30). 9571/1: Mesztegnyő „Soponyai-tó és SziliBükk között” K1a (K: 1991). 9571/3: Nagybajom „Bükk” K1a, K5 (K: 1992), „Fehér-tó” J6, K1a (K: 1995). 9669/4: Somogyszob „Bükki-malom” J5, K1a, K5 (KeVEY 2013a: 30), „Rinyaerdő" J5, K1a, K5 (K: 1984). 9769/4: Szenta „Kiskunovica” J5 (K: 1982). 9771/1: Nagykorpád „Mórici-erdő” J5, K1a (KeVEy 2013a: 30). 9771/3: Mike „Patkány-domb” J5, K1a (K: 1996). 9869/3: Bélavár „a vasútmegállótól a Palinai-erdő felé vezető út melletti erdőben” K1a, K5 (KEveY 2013a: 30), „Szőlő-hegy=Kerék-hegy” K1a, K5 (K: 1984). 9870/1: Rinyaszentkirály „Ág-erdő” J5, J6 (K: 1997), „Polai-erdő” J6, K1a (KeveY 2013a: 30). V: 9775/1: Kisvaszar „Hosszú-erdő” K1a (K: 2004), „Bikági-völgy” J5, J6, K1a, K5 (K: 1978). 9775/2: Ág „Vágyom-völgy” J5, J6, K1a, K5, LY1 (K: 1997). Mcs: 9776/1: Vékény „Zsidópokol” LY1 (KEVEY 1993b: 45). 9776/2: Váralja „Farkas-árok” K5, LY1 (KevEY 1993b: 45). 9776/4: Mecseknádasd „Templom-hegy” K5, LY1 (K: 2001). BDs: 0171/2: Lakócsa „Alsóerdő" K1a (KEVEY 2007b: 48).

Petasites albus (L.) Gaertn. - BDs: 0172/4: Drávasztára „Kisvájás” J4 (KEvEY in KEvEY \& TóTH V. 2006: 56).

Primula veris L. - Mf: 8976/4: Soponya-Nagyláng „Park-erdő” J6, K1a (KeveY 1983: 21). 9076/2: Káloz „Belmajor” J6 (K: 1984). Mindkét helyen talán ültetve! Cssz: 8780/1: Tököl „Tököli-erdő” J6 (KeveY 1995: 49). B: 8771/4: Bakonyjákó-Iharkút „Sármás” LY4 (K: 2015). 
8872/2: Márkó „Csordás-árok” K2, LY4 (K: 2014). Ba: 8770/4: Kup „Kupi-erdő” J5, K1a (K: 1975). BS: 9571/1: Somogyfajsz „Nadalos”! P45 (NovACSEK 1996: 260). Th: 9377/1: Nagyszékely „Hideg-völgy” (PILlich 1930: 30). A szerző - a településhatárok megjelölése nélkül - három helyről közli a növényt. A felsorolt dűlőnevek közül csak a „Hideg-völgy”-et sikerült azonosítani, míg a „Mogyorófo”" és a „Hosszú-erdő” hollétét nem tudtam kideríteni. Megjegyezném, hogy nem sokkal előbb a szerző (PILlich 1928: 96) Simontornya környékéről - a konkrét lelőhelyek megjelölése nélkül - említette a növényt. Újabb adata nincs!

Primula vulgaris Huds. - Mf: 9176/2: Dég „Kastély-park” J6 (FEKETE, JAKUCS \& ZÓLYOMI in ZÓlYOMI 1958: 638; MAJER 1979: 10; KeVEY 1984: 53). B: 8872/4: Szentgál „Mecsek-hegy” K2, K5, LY2, LY4 (K: 2007). Ba: 8672/1: Fenyőfo „Kuruc-erdő” K1a (KeVEY 2014b: 60; KeVEY 2015f: 48). - Pápateszér „Görgő-ér” K1a (KEvEY 2014b: 60; KEvEY 2015f: 48), „Mehetősierdő" K1a (Kevey 2014b: 60; Kevey 2015f: 48). 8871/3: Devecser „Széki-erdő” K1a (K: 2003). Khg: 9169/3: Cserszegtomaj „Csóka-kő” LY1, LY2 (K: 2000). 9170/3: Lesencefalu „Somos-tető” K2, K5 (K: 1987). 9170/3: Nemesvita „Sárkány-erdő” K2, K5 (K: 1986). 9269/2: Balatongyörök „Kígyós-völgy” K2, K5 (K: 1986). 9269/2: Gyenesdiás „Büdöskútivölgy” K2, K5 (K: 1986). ÉZ: 9068/4: Vindornyaszőlős „Felső-erdő” K1a (K: 1993). 9168/3: Nagykapornak „Vecei-erdo”” K2 (K: 1992). DZ: 9566/2: Valkonya „Valkonyai-erdő: a becsehelyi műút mellett” K2, K5 (K: 2008). Mh: 9370/1: Balatonberény „Diósi-erdő” K2 (K: 1976). BS: 9470/4: Marcali „Kis-Gyóta” J6, K1a (Kevey 2013a: 30). 9570/4: Böhönye „Tranglus-erdő” K1a (Kevey 2013a: 30). - Nagybajom „Szili-Bükk és Lencsenpuszta között” K1a (Kevey 2013a: 30). 9571/3: Nagybajom „Felső-Csikotai-erdő” K1a (KeveY 2013a: 30). 9770/3: Nagyatád „Simongáti-erdő” J6, K1a (K: 1990). 9771/1: Nagykorpád „Mórici-erdő” K1a (KeveY 2013a: 30). KS: 9472/1: Somogyvár „Télizöld” K2 (K: 1998). Zs: 9773/1: Cserénfa „Tábor-völgy” J5, J6, K2, K5 (K: 1982). 9774/1: Baranyajenő „Kósa-gödör” K1a, K2, K5 (K: 1996). 9774/3: Palé „Nagy-hegy” K2 (K: 1989). 9774/4: Sásd „Herceg-erdő” K2 (K: 2008). 9872/4: Szulimán „Kis-erdő” K2 (K: 2015). Bd: 9975/3: Kökény „Malom-völgy” K2 (K: 1994). 9975/4: Pécs-Nagyárpád „Pécsudvardi-erdő” K1a (K: 1977).

Scutellaria altissima L. - Mf: 8976/4: Soponya-Nagyláng „Kastély-park” J6, K1a (KEVEY 1983: 21). Msz: 0078/4: Kölked „Alsó-Béda” J6 (O-KovÁcs in KEVEY \& O.KovÁcs et al. 1992: 18). Mcs: 9776/3: Vékény „Szószék” LY2 (K: 1982). - Váralja „Csalán-hegy” LY2 (K: 1983). Vlhg: 0175/2: Bisse „Pécsi-Lapis” K2 (KeVEY 2016: 38). Bd: 0075/2: Egerág „Halastói-erdő” K1a (K: 2013). 9975/4: Nagyárpád „Pécsudvardi-erdő” K1a (K: 1977). Szd: 9777/2: Szálka „Felső-erdő” K2 (K: 1988).

Stellaria alsine Grimm - VRv: 8867/3: Rum „Rumi-erdő” J 4 (K: 2016).

Trollius europaeus L. - BS: 9571/4: Újvárfalva „Bagó-rét” D5 (NOVACSEK in KEVEY 1990: 85).

Vicia oroboides Wulfen - VRv: 8965/3: Kemestaródfa „Bagólé-erdő” K1a (KEVEY 2015e: 228). DZ: 9466/1: Lasztonya „Cigány-árok” LY1, K5 (KEVEY 2008a: 44/7. táblázat). 9467/1: Bucsuta „Börzöncei-hegy” K2, K5 (K: 2009), „Guricsányi-erdő” K2, K5 (K: 2009). 9468/1: Újudvar „Csibiti-völgy” K2, K5, LY1 (K: 2006). 9468/2: Zalakaros „Kanica-erdő” K2, K5, LY1 (Kevey 2008a: 44/7. táblázat). 9568/4: Nagykanizsa-Kisfakos „Virág-hegy” K2, K5 (Horvát A. O., Kevey \& Novacsek ined.: 1974). 9667/2: Belezna „Szaplányosi-erdő” J6, K2 (K: 1987). 9668/1: Liszó „Medvés” K2, K5 (K: 1987). 9668/2: Iharosberény „Szentpáli-erdő” K2, K5 (K: 1987). 9668/4: Csurgónagymarton „Gágyi-erdo”! K2, K5 (Toldi ex verb.: 2012). Zd: 9767/2: Zákány „Vasút-oldal: Hagymás” K2, K5 (KeVEY 2008a: 43/7. táblázat). - Őrtilos „Szentmihály-hegy: Templom-völgy, Templom-hegy” K2, K5 (KEVEY 2008a: 43/7. táblázat). Zs: 9673/3: Cserénfa „Tábor-völgy” K2, K5 (K: 1975). - Kaposvár „Vas-kapu” K2, K5 (K: 2006). 9673/4: Szentbalázs „Hercegképe” K2, K5 (K: 2016). 9773/1: Gálosfa „Vörösalmaerdő” K2, K5 (K: 1977). - Kaposgyarmat „Lozsit-kút” K2, K5, LY1 (KeVEY 2010: 41; KevEY 2013c: 35). 9773/3: Bőszénfa „Farkaslaki-erdő” K2, K5 (K: 1977), „Fácános” K2 (K: 1984). - 
KEVEY (2017): Pótlások Magyarország edényes növényfajainak elterjedési atlaszához IV.

Almamellék „Terecsenypuszta” K2, K5 (K: 2011). 9774/2: Meződ „Jakab-domb”! K2 (Havasi \& Tóth I. Zs. ined.: 2008). 9774/4: Sásd „Iván-völgy”! K2 (Havasi ined.: 2007). 9873/1: Almamellék „Sas-rét” K2, K5 (K: 2011).

\section{Monocotyledonopsida}

Arum orientale M. Bieb. - Mm: 8869/4, 8870/2: Tüskevár „Tüskevári-erdo”” J6, K1a (K: 2011). Mf: 8678/4: Martonvásár „Park-erdő” J5, J6, K1a (BoRos in KEVEY 1987b: 36). 8976/4: Soponya-Nagyláng „Fácános-erdő” J6 (K: 1977). „Kastély-park” J6, K1a (K: 1981). 8977/1: Aba „Felsőszentiváni-erdő” J6 (K: 1999). 8977/2: Sárosd „Kastély-park” J6 (K: 1998). 9076/2: Káloz „Belmajor: Park-erdő” J6 (K: 1984). 9277/4: Vajta „Park-erdő” J6, K1a, L5 (KeVEY in KeveY \& LENDVAI 2015: 22). 9278/3: Németkér „Barát-erdő” K1a, L5 (KeveY in Kevey \& LendVAi 2015: 22), „Öreg-erd”” K1a, L5 (KeveY in KeVEY \& LendVAi 2015: 22). 9278/4: Németkér „Körtvélyesi-erdő” K1a (KevEY in KEVEY \& LENDVAI 2015: 22). 9377/2: Vajta „Nagy-erdő” K1a, L5 (KeVEY in KEVEY \& LENDVAI 2015: 22). 9378/1: Vajta „Nagy-erdő” K1a, L5 (KEVEY in KeVEY \& LENDVAI 2015: 22). - Bikács-Kistápé „Csorda-mező” K1a, L5 (Kevey in Kevey \& LendVAi 2015: 22), „Tölgyfamajor” J6 (K: 1980). DTk: 8782/1: Csévharaszt „Pótharaszti-erdő” K1a, L5 (K: 2016). ÉZ: 9068/4: Vindornyaszőlős” „Felsőerdő” K1a (KeveY 1995: 50). KS: 9472/1: Somogyvár „Télizöld” J5, K2 (K: 1998). 9575/2: Döbrököz „Hajagos-erdő” K1a (K: 1994). BS: 9471/1: Csömend „Koszód” J6 (Kevey 1983: 22).

Carex pallescens L. - Mcs: 9776/3: Szászvár „Somlyó” K7b (K: 2016).

Carex pseudocyperus L. - BSzS: 7901/1: Nagyar „Tisza-ártér” J4 (KEVEY \& BARNA 2015: 88). Mf: 9176/2: Dég „Kastély-park” J2 (K: 2004). 9378/2: Németkér „Fekete-tó” J1a, J2 (KevEY \& Tóth I. Zs. 2016: 19), „Barát-erdő” J1a, J2 (KeveY \& TóTH I. Zs. 2016: 19). Zd: 9667/3, 9767/1, 9767/2: Őrtilos „Visszafolyó-patak” J1a, J2 (KeVEY \& ToLDI 2013: 54). BS: 9470/4: Marcali „Kis-Gyóta” J1a, J2 (K: 2008). 9570/2: Hosszúvíz „Színai-berek” J2 (K: 2008). Mesztegnyő „Dávodi-erdő erdőrezervátum” J2 (K: 2008). 9571/1: Mesztegnyő „Felső-Kak” J2 (K: 2008). 9769/1: Szenta „Baláta-tó” J1A, J2 (Borhidi \& Kevey ined.: 1990).

Carex strigosa Huds. - Sz: 7969/3: Rajka (РЕCK 1878: 45) „a Duna melletti ligetekben” (HEufFel 1831: 405), „Dunamenti szigetek nedvesebb erdeiben” (HEufFel 1862: 707). Má: 9465/3: Tornyiszentmiklós „Mura-erdo”” J5, K1a, K5 (KIRÁLY G. in KeVEY 2015a: 55; KevEY 2015a: 55). 9566/3: Letenye „Goronyáki-erdo” J6 (KeVEY 2015a: 55), „Murcsek” J4, J6 (KEVEY 2015a: 55). B: 8771/4: Bakonyjákó „Németbánya felé, a Bittva-patak mentén” J5 (K: 2015). Három kissé távolálló helyen egy-egy kicsiny populáció, néhány egyeddel. A Bakony flórajárására (Vesprimense) új! A Magyar-Középhegységen eddig csak a Keszthelyi-hegység és a Börzsöny egy-egy pontjáról ismertük (vö. KEVEY 2001b: 40). DZ: 9466/3: Kiscsehi „Pityer-domb” K1a (K: 2009). 9567/2: Hosszúvölgy „Zsigárdi-erdő” J6. K1a (K: 2015). Zs: 9772/3: Visnye „Boros-erdő” K1a (K: 2016). V: 9676/1: Lengyel „Hőne-források” (TóTH I. Zs. in KeVey 2015a: 55). Mcs: 9776/2: Hidas „Vad-víz-árok” J5 (Kevey 2015a: 55).

Festuca drymeia Mert. et W.D.J. Koch - Vlhg: 0175/2: Bisse „Pécsi-lapis” K2, K5 (KeVEY 1987a: 1. táblázat). - Kistótfalu „Átai-hegy” K2, K5 (KEVEY 1987a: 1. táblázat).

Hordelymus europaeus (L.) Less. ex Harz - B: 8671/4: Ugod „Somberek” K2, K5 (K: 2015). 8771/2: Bakonyjákó-Iharkút „Sármás” K2, LY4 (K: 2015). Khg: 9169/2: Zalaszántó „Tinóhálás” K1a (K: 2006). BDs: 0072/2: Bürüs „Sikota” K1a (Kevey 1981: 181). BS: 9570/2: Mesztegnyő „Búsvár” K1a (KEvey 1993a: 58). 9771/1: Nagykorpád „Mórici-erdő” K1a (K: 2017). Mcs: 9874/3: Bakonya „Sás-völgy” K2, K5 (K: 1978). Szd: 9777/2: Szálka „Felső-erdő” K2, K5 (K: 1988).

Leersia oryzoides (L.) Sw. - Mf: 9176/2: Dég „Kastély-park” J2 (K: 2004). BSzS: 7800/3: Jánd „Holt-Tisza” J4 (KeveY \& BARNA 2015: 90). 7801/4: Szatmárcseke „Tisza-ártér” J4 
(Kevey \& BARna 2015: 90). 7899/2: Gyüre „Szalkaszeg” J4 (Kevey \& BARNA 2015: 90). 7901/1: Nagyar „Tisza-ártér” J4 (Kevey \& BARNA 2015: 90). BS: 9570/2: Hosszóvíz „Színaiberek” J5 (K: 2008). - Mesztegny” „Dávodi-erdő erdőrezervátum” J2 (Kevey 2013a: 28).

Leucojum aestivum L. - Cssz: 8680/1: Budapest „Háros-sziget” J4 (KEVEY \& HuSZÁR 1999: 42). 8779/3: Szigetúffalu „Újfalusi-erdő” J6 (K: 1978). 8879/1: Ráckeve „Schilling-erdő” J6 (K: 1978). 8879/3: Lórév „Makádi-erdő” J6 (K: 1978). 8979/1: Makád „Rókás” J6 (K: 1983). 8979/4: Makád „Sasréti-erdő” J6 (K: 1990). 9079/2: Rácalmás „Kis-sziget” J4 (K: 1998). Gd: 9777/2: Bonyhád-Alsóbörzsöny „Felső-rétek” J4 (TóTH I. Zs. ined.: 2013).

Leucojum vernum L. - R: 8468/1: Kapuvár „Rába-erdő” K1a (K: 2005). Mf: 8977/2: Sárosd „Kastély-park” J6 (K: 1998). Valószínúleg ültetve! Khg: 9169/2: Zalaszántó „Vár-berek” J5 (K: 1993a: 57). ÉZ: 9267/3: Pölöske „Sohollár” J5 (K: 2014). BS: 9470/4: Marcali „KisGyóta” J6 (K: 1997), „Nagy-Gyóta” J6 (KevEY 2013a: 31). 9569/1: Somogysimonyi „Gödörberki-erdő" J5 (K: 1998). 9571/3: Nagybajom „Felső-Csikotai-erdő” J5, K1a, K5 (KeveY in KeveY et al. 1998: 251; KeveY 2013a: 31), „Bükk” K1a, K5 (KeveY et al. 1998: 251).

Listera ovata (L.) R. Br. - Sz: 8271/1: Győrladamér "régi kavicsbánya” (ALEXAY in KEVEY \& AlEXAY 1992: 34). 8271/2: Vámosszabadi „Szilfás” J6 (ALEXAY in KeveY \& AlEXAY 1992: 34). H: 8270/3: Lébény „Bormászi-erdő” J6 (KevEY 2015a: 54). Mm: 8870/1: Doba „Felső-erdő” J6 (Kevey 2015a: 54). 9069/1: Zalagyömörő „Nyirlakpusztai-erdő” J6 (Kevey 2015a: 54). Mf: 9075/3: Enying „Kustyán-erdő” J5 (K: 2004). 9176/2: Dég „Őztelek” J6 (MAJER 1979: 10; KEVEY 1984: 53). 9378/3: Nagydorog „Fürdő-erdő” K1a (KeveY in KeveY \& LendvaI 2015: 23). 9478/3: Tengelic „Középtengelic” K1a (KEveY in KevEY \& LeNDVAI 2015: 23). Sk: 9679/1: Bogyiszló „Orchideás-erdő" S2 (KALOTÁs in Kevey \& TótH I. 2000: 140), „Taplós” (KALOTÁS in KEVEY \& TóTH I. 2000: 140). HNs: 0176/2: Kisjakabfalva „Vizes-erdő" K1a (K: 1980). DTk: 8781/1: Ócsa „Nagy-erdő” J5, J6 (K: 2015). Ny: 8496/4: Debrecen „Halápierdő" J6 (Papp L. \& Kevey ined.: 2004). 8497/2: Nyíracsád "Jónás-rész" J6, K1a (Papp L. \& Kevey ined.: 2003). 8100/3: Mérk „Vadaskerti-erdő” J6, K1a (Papp L. \& Kevey ined.: 2004). 8498/1: Nyírábrány „Mogyorósi-erdő” J6, K1a (Papp L. \& Kevey ined.: 2004), „Kiskőrises” J6 (Papp L. \& Kevey ined.: 2007). Bk: 7695/4: Sátoraljaújhey „Long-erdő” J6 (K: 2013). G: 8377/1: Héreg „Mészberki-kút” K2 (Kevey 2015a: 54). B: 8872/1: Herend „Molnártanya” J5 (K: 2008). Ba: 8672/1: Pápateszér „Görgő-ér” J5, K1a (K: 2002). A flóraatlasz 1950 előtti előfordulásként tünteti fel. Khg: 9169/2: Zalaszántó „Vár-berek” J5, K1a (K: 2009). BS: 9469/3: Zalakomár-Ormándpuszta „Csöngo-kút” J5, J6 (K: 1989). 9470/4: Marcali „KisGyóta” J6, K1a (K: 1994), „Nagy-Gyóta” K1a (KeveY 2013a: 30). 9570/2: Hosszúvíz „Színaiberek” J5, J6 (K: 1995). 9570/4: Böhönye „Tranglus-erdő” (JUHÁSZ in KEVEY \& JuHÁsz et al. 1992: 36). A flóraatlasz 1990 előtti előfordulásként tünteti fel! - Nagybajom „Lencsenpuszta és Szili-Bükk között” K1a (KEVEY in KEvEY \& JuHÁsz et al. 1992: 36). 9571/3: Nagybajom „Bükk” K1a, K5 (KeVEY \& KLUJBER in KeVEY \& JuHÁsZ et al. 1992: 36), „Fehér-tó” K1a (K: 1992), „Alsó-Kak” J6, K1a (KeveY \& NovACSEK in KeVEY \& JuHÁsZ et al. 1992: 36), „Közép-Kak” K1a (KeveY in KeveY \& JuHÁsZ et al. 1992: 36), „Felső-Csikotai-erdő” J5, K1a, K5 (JuHÁsZ in KeveY \& JuHÁsZ et al. 1992: 36). 9769/4: Szenta „Kiskunovica” J5 (K: 1982). 9771/1: Nagykorpád „Mórici-erdő” J5, K1a (KEvEY 2013a: 30). 9870/1: Rinyaszentkirály „Polai-erdő” J6, K1a (KEvEY 2013a: 30). A flóraatlasz 1950 előtti előfordulásként tünteti fel! Zs: 9673/3: Cserénfa „Tábor-völgy” K1a (K: 1984). A flóraatlasz 1950 előtti előfordulásként tünteti fel!

Melica picta K. Koch - Ny: 8199/4: Terem „Nagyfenék” K1a (K: 1994).

Melica transsylvanica Schur - Köv: 9193/1: Bélmegyer „Szolga-erdő” M3 (K: 2002).

Ornithogalum brevistylum Wolfner - Tt: 8595/1: Ebes „Ondód” OC (KEVEY 2015a: 52). 8791/1: Karcag „Magyarka” OC (Kevey 2015a: 52). Mcs: 9875/2: Komló „a zobáki műút melletti erdőben” K2 (K: 2015). Vlhg: 0176/2: Villány „Szőlő-hegy” OC (Vöröss L. Zs. \& Kevey ined.: 1970). 
Veratrum album L. - Mm: 8870/1: Dáka „Tilos-erdő” J5 (Kevey \& Alexay ined.: 2010). B: 8773/4: Olaszfalu-Alsópere „Puszta-berek” J5 (K: 1996). BS: 9469/3: ZalakomárOrmándpuszta „Csöngő-kút” J5, J6 (K: 1988). 9470/4: Marcali „Nagy-Gyóta” J5, J6 (K: 1994). 9471/3: Libickozma „Kopári-erdő” K1a (KeVEy 2013a: 34). 9569/1: Somogysimonyi „Gödörberki-erdő” J5, J6 (K: 1998). 9570/2: Hosszúvíz „Színai-berek” J5, J6 (K: 1995). Mesztegnyő „Búsvár” J5 (K: 1992), „Dávodi-tó és Somonyai-tó között” J2, J5, J6, K1a (KEveY 2013a: 34). 9570/4: Böhönye-Dávodpuszta „Tranglus-erdő” K1a (KeveY 2013a: 34), „Halastói-erdő” J6 (K: 1993), „Halászház” J5 (K: 1991). - Nagybajom „Cífratanya és Dávoditó között” J5, J6 (K: 1993). 9571/3: Nagybajom „Fehér-tó” J5, K1a (K: 1996), „Bükk” K1a (K: 1992). 9769/4: Szenta „Kiskunovica” J5 (K: 1982). 9771/1: Nagykorpád „Mórici-erdő” J5, K1a (Kevey 2013a: 34). 9870/1: Rinyaszentkirály „Ág-erdő” J5, J6 (K: 1997), „Polai-erdő” J6, K1a (KEVEY 2013a: 34).

Veratrum nigrum L. - B: 8870/1: Doba „Somló” LY2, LY4 (K: 1989). 8771/2: BakonyjákóIharkút „Sármás” K2, LY4 (K: 2015). Khg: 9069/3: Zalaszántó „Kovácsi-hegy” K2, LY2, LY4 (K: 2005). BS: 9871/1: Lábod „Szarvas-dülő” J6 (K: 1988). 9471/3: Libickozma „Kopárierdő” K1a (Kevey 2013a: 34). 9570/2: Mesztegnyő „Búsvár” K1a (Kevey 2013a: 34), „Dávodi-erdő erdőrezervátum” K1a, K5 (KeveY 2013a: 34). 9571/1: Mesztegnyő „Mélyéger” K1a (Kevey 2013a: 34). 9669/3: Szenta „Baláta-tó” K1a, L2b (Borhidi \& Kevey ined.: 1990).

\section{Téves, kétes és ellenőrízendő adatok a flóraatlaszban}

A gyorsan, határidővel végzett flóratérképezés kapcsán sajnos téves adatok is kerültek a térképekre. Meglátásom szerint e tévedések elsősorban a terepmunkák során történtek. A kérdéses terület flóráját kellően nem ismerő térképező ugyanis felületes megfigyelés, téves határozás, vagy elírás révén téves adatokat is rögzíthetett az adatlapokra, ahonnan ezek a flóraatlasz (BARTHA et al. 2015) térképeire kerültek. Az alábbi hét faj esetében találtam ilyen téves adatokat:

\section{Chaerophyllum aromaticum $\mathrm{L}$.}

Zs, Mcs: Zselici és mecseki adatainak (9874/1; 9874/2; 9874/3; 9874/4; 9875/3) helyességét megkérdőjelezem. E növényt egész Dél-Dunántúlon nem láttam. Szokatlan, hogy hirtelen öt egymás melletti kvadrátban is előkerült? Felületes megfigyeléssel az Aegopodium podagraria L. fajjal összetéveszthető. Amennyiben mégis előfordul, az adatok helyességét pontosan dokumentálni kell.

\section{Equisetum telmateia Ehrh.}

Ismereteim szerint a növény az Alföldön igen ritka (vö. Soó 1964: 516; VöRöss 1988: 122). Ennek ellenére a flóraatlaszban (BARTHA et al. 2015: 42) viszonylag sok (32 kvadrát) helyen szerepel. Ezzel kapcsolatban felmerül a gyanú, hogy egyes lelőhelyek talán nagyra nőtt Equisetum arvense-re vonatkozhatnak? Nem ártana ezért e lelőhelyeket ellenőrizni és dokumentálni.

\section{Leucojum vernum $\mathrm{L}$.}

CsSZ: BARTHA et al. (2015: 263), valamint DÉNES (1999: 295) térképén két előfordulás van jelezve $(8680 / 1,8979 / 4)$, amelyek hitelességét erősen kétlem. Feltételezhetően elírás. Szinte biztos, hogy e két adat a Leucojum aestivum L. fajra vonatkozik, amely a Csepel-szigeten gyakori. A Leucojum vernum - ha itt valóban megtalálható - előfordulását egyértelműen meg kell erősíteni. 


\section{Lunaria rediviva $\mathrm{L}$.}

Zs, Bd, Vlhg: Néhány kvadrátban való előfordulása törlendő: 0075/4, 0175/1, 0175/2, 9873/4. Az érintett területeket igen jól ismerem, ezért szinte kizártnak tartom az adatok helyességét. Felvettem a kapcsolatot az adatszolgáltatókkal, de ők sem emlékeznek az előfordulásra, bár az általuk leadott adatlap tartalmazza a növény nevét. Valószínűleg elírással, vagy félrehatározással (Lunaria annua L.) állunk szemben.

Mcs: A flóraatlasz a 9975/1 kvadrátból jelzi. Felvettem a kapcsolatot az adatközlővel. CSIKY (ex litt: 2016) szerint e kvadrátban valóban előfordul a növény, de a szomszédos kertekből vadult ki, ezért a térképen nem körrel, hanem háromszöggel kell jelölni.

\section{Mercurialis perennis $\mathrm{L}$.}

Sz: Szigetközi adatai $(8069 / 3,4 ; 8169 / 4 ; 8170 / 3,4 ; 8270 / 3,4)$ a térképről (BARTHA et al. 2015: 147) mind törlendők. 23 éven át rendszeresen kutattam a Szigetköz erdeit, amelyekből több mint 1000 cönológiai felvételt készítettem, de egyik jegyzetlapomon sem fordul elő a növény. Egészen biztos, hogy az adatok elírás, vagy téves adatközlés révén kerülhettek a térképre.

\section{Oxalis acetosella $\mathrm{L}$.}

BS: Tapasztalatom szerint a homokvidéken e növény ritka. Ehhez képest a flóraatlasz térképén (BARTHA et al. 2015: 196) több mint húsz helyen szerepel, mely adatok egy részét megkérdőjelezem. Ezek valószínúleg az Oxalis stricta L. fajra vonatkozhatnak, amely BelsőSomogy erdeiben a nyiladékok és az erdei földutak mentén elég gyakori. Szükség lenne ezért egyes adatok felülvizsgálatára. A térkép több olyan helyről is jelzi a növényt, ahol én rendszeresen kutattam, de ott csak az Oxalis stricta L. fordul elő. Belső-Somogy homokvidékén az Oxalis acetosella-t csak előbb, az enumeratio-ban felsorolt helyeken láttam. Vlhg: A flóraatlasz (BARTHA et al. 2015: 196) a Villányi-hegység két kvadrátjából (0175/1; 0175/2) jelzi a növényt. A területet nagyon jól ismerem, s az adatközlő sem tud a növény előfordulásáról. Biztos, hogy téves adatközlésről, elírásról, vagy félrehatározásról (Oxalis stricta L.) van szó.

Th: A flóraatlasz térképe (BARTHA et al. 2015: 196) a Tolnai-hegyháton három kvadrátot (9477/2; 9577/2;9577/3) jelöl meg. Tudtommal e területen nincsenek olyan erdők, amelyek a növény számára élőhelyet jelenthetnének. Valószínúleg téves adatközlésről, vagy félrehatározásról (Oxalis stricta L.) van szó, ezért e három adat - ha megerősítést nem nyer törlendő.

\section{Primula veris $\mathrm{L}$.}

Mh, KS, Zs, Bd: A flóraatlasz (BARTHA et al. 2015: 207) az alábbi kvadrátokról jelzi a növény előfordulását: 9273/1; 9273/3; 9470/1; 9772/3; 9773/1; 9773/2; 9773/3; 9773/4; 9774/1; 9774/2; 9774/3; 9774/4; 9872/2; 9872/4; 9873/1;9873/3;9873/4; 9974/1; 9975/3. Az adatszolgáltatók közül senki sem emlékszik a faj e kvadrátokban való előfordulására. A kérdéses tájak erdeit jól ismerem. Ezen adatok valószínűleg elírás, vagy meddő állapotban való téves felismerés (Primula vulgaris HuDS.) révén kerültek a flóraatlaszba. Amennyiben a fenti kvadrátok némelyikében mégis megtalálható a növény, az előfordulást egyértelműen bizonyítani kell.

\section{Köszönetnyilvánítás}

Köszönetem illeti azon kollégákat, akik közöletlen adataikat rendelkezésemre bocsátották, s ezzel gazdagították dolgozatom tartalmát: Alexay Zoltán, Barna Csilla, Borhidi Attila, Csete Sándor, Csiky János, Deme Tamás, Havasi László, Horvát Adolf Olivér†, Juhász Magdolna, 
Kurucz Gábor, Lelkes András, Lendvai Gábor, Majláth Imre, Molnár Marcel, Novacsek Péter†, Papp László, Pintér András, Sonnevend Imre, Toldi Miklós, Tóth István Zsolt, Vöröss László Zsigmond†. Köszönetem illeti lektoraimat (Bartha Dénes, Schmidt Dávid) is javító szándékú megjegyzéseikért.

\section{Irodalom}

Bartha D., Király G., Schmidt D., Tiborcz V., Barina Z., Csiky J., JAKAB G., LeSku B., SchmotZer A., VidéKi R., VojtKó A., ZólYomi Sz. (szerk.) (2015): Magyarország edényes növényfajainak elterjedési atlasza. Nyugat-magyarországi Egyetem Kiadó, Sopron, 329 pp.

Boros Á. (1970): Florisztikai közlemények V. - Botanikai Közlemények 57 (1): 69-72.

BölöNi J., MolNÁR Zs., Kun A. (szerk.) (2011): Magyarország élőhelyei. Vegetációtípusok leírása és határozója. ÁNÉR 2011. - MTA Ökológiai és Botanikai Kutatóintézete, Vácrátót, 441 pp.

DÉNES A. (1999): Tavaszi tőzike (Leucojum vernum L.). In: FARKAS S. (szerk.), Magyarország védett növényei. - Mezőgazda Könyvkiadó, Budapest, pp. 295.

HANGAY O. (1889): Erőszakolt flóravidék. - Orvos-Természettudományi Értesítő 11 [14(2)]: 153-162.

Heuffel J. (1831): Verzeichnis der um Pressburg vorkommenden, in Endlicher's Flora Posoniensis nicht erwähnten Pflanzen. - Flora oder allgemeine botanische Zeitung 1: 404-407.

Heuffel J. (1862): Fragmenta Monographiae Caricum in regnis Hungariae, Croatiae, Slavoniae, magnoque Transylvaniae principatu sponte nascentium. - Linnaea (Ein Journal für die Botanik in ihrem ganzen Umfange) 31 (1861-1862): 659-728.

JárAI-Komlódi M. (1958): Die Pflanzengesellschaften in dem Turjángebiet von Ócsa-Dabas. - Acta Botanica Academiae Scientiarum Hungaricae 4: 63-92.

KÁRoLYI Á. (1949): Botanikai megfigyelések Nagykanizsa környékén. - Borbásia 9 (3-5): 18-21.

KÁRolyi Á. \& Pócs T. (1968): Délnyugat-Dunántúl flórája I. - Acta Academiae Paedagogicae Agriensis, Nova Series 6: 329-390.

KÁRPÁTI V. (1963): Die zönologischen und ökologischen Verhältnisse der Wasservegetation des DonauÜberschwemmungsraumes in Ungarn. - Acta Botanica Academiae Scientiarum Hungaricae 9: 323-385.

KEVEY B. (1981): Adatok Magyarország flórájának és vegetációjának ismeretéhez I. - Botanikai Közlemények 67 (3): 179-182.

KEVEY B. (1983): Adatok Magyarország flórájának és vegetációjának ismeretéhez II. - Botanikai Közlemények 70 (1-2): 19-23.

KeveY B. (1984): Dég parkerdeinek tölgy-kőris-szil ligetei. - Botanikai Közlemények 71 (1-2): 51-61.

KEVEY B. (1985a): Adatok Magyarország flórájának és vegetációjának ismeretéhez III. - Botanikai Közlemények 72 (1-2): 155-158.

KeveY B. (1985b): Fragmentális szurdokerdők a Villányi-hegységben. Fragmentale Klamm-Wälder im Villány-Gebirge, Süd-Ungarn. - Janus Pannonius Múzeum Évkönyve 29 (1984): 23-28.

Kevey B. (1987a): A Villányi-hegység bükkösei. The beech-woods of the Villány Mountains, South Hungary. - Janus Pannonius Múzeum Évkönyve 30-31 (1985-1986): 7-9.

Kevey B. (1987b): A martonvásári Kastélypark tölgy-kőris-szil ligeterdői. - Botanikai Közlemények 73 (1-2) (1986): 33-42.

KEVEY B. (1988): Adatok Magyarország flórájának és vegetációjának ismeretéhez IV. - Botanikai Közlemények 74-75 (1-2) (1987-1988): 93-100.

KEvEY B. (1990): Adatok Magyarország flórájának és vegetációjának ismeretéhez V. - Botanikai Közlemények 80 (1): 83-96.

KeveY B. (1993a): Adatok Magyarország flórájának és vegetációjának ismeretéhez VI. - Botanikai Közlemények 80 (1): 53-60.

KeveY B. (1993b): A Keleti-Mecsek szurdokerdei (Scutellario-Aceretum). Die Klammwälder des östlichen Mecsek (Scutellario-Aceretum), Süd-Ungarn. - Folia Comloensis 5: 29-54.

KEVEY B. (1995): Adatok Magyarország flórájának és vegetációjának ismeretéhez VII. - Botanikai Közlemények 82 (1-2): 45-53.

Kevey B. (1997): A Nyugati-Mecsek szurdokerdei [Scutellario altissimae-Aceretum (HoRvÁT A. O. 1958) Soó et BorHidi in Soó 1962]. In: BorHIDI A. \& SzABó L. Gy. (szerk.), Studia Phytologica Jubilaria. Dissertationes in honorem jubilantis Adolf Olivér Horvát doctor academiae in anniversario nonagesimo nativitatis 1907-1997. - Janus Pannonius Tudományegyetem Növénytani tanszék, Pécs, pp. 75-99. 
KEVEY B. (2001a): Adatok Magyarország flórájának és vegetációjának ismeretéhez VIII. - Botanikai Közlemények 88 (1-2): 95-105.

Kevey B. (2001b): A Carex strigosa Huds. magyarországi elterjedése. - Kitaibelia 6 (1): 37-44.

KEVEY B. (2004): Adatok Magyarország flórájának és vegetációjának ismeretéhez IX. - Botanikai Közlemények 91 (1-2): 13-23.

KeveY B. (2007a): A somogyi-Dráva-ártér gyertyános-tölgyesei (Circaeo-Carpinetum BorHIDI 2003 em. Kever hoc loco). - Somogyi Múzeumok Közleményei 17 (2006): 83-102.

KEveY B. (2007b): A baranyai Dráva-sík gyertyános-tölgyesei (Circaeo-Carpinetum Borhidi 2003 em. KeVEY 2006). - Natura Somogyiensis 10: 41-71.

KEveY B. (2007c): A Somogyi-Dráva-ártér tölgy-kőris-szil ligetei (Fraxino pannonicae-Ulmetum Soó in AszóD 1935 corr. Soó 1963). - Somogyi Múzeumok Közleményei 17 (2006): 103-122.

Kevey B. (2008a): Magyarország erdőtársulásai (Forest associations of Hungary). - Tilia 14: 1-488. + CD-adatbázis (230 táblázat + 244 ábra).

KEVEY B. (2008b): Szurdokerdő-fragmentumok a Zákányi-dombokon (Polysticho setiferi-Aceretum pseudoplatani KeVEY in BoRHIDI et KeVEY 1996). - Natura Somogyiensis 12: 31-46.

KEVEY B. (2009): A Zákányi-dombok égerligetei (Carici pendulae-Alnetum glutinosae BoRHIDI et KeVEY 1996). - Kanitzia 16 (2008-2009): 211-231.

Kevey B. (2010): A Zselic szurdokerdei (Polysticho setiferi-Aceretum pseudoplatani KeVEY in BoRHIDI et KeveY 1996). - Natura Somogyiensis 17: 23-48.

KEVEY B. (2012a): Töredékes tölgy-kőris-szil ligetek a Zákányi-dombokon (Knautio drymeiae-Ulmetum BORHIDI et KEVEY 1996). - Natura Somogyiensis 22: 5-26.

Kevey B. (2012b): A Villányi-hegység molyhos tölgyesei. - e-Acta Naturalia Pannonica 4: 35-58.

KEVEY B. (2013a): Belső-Somogy homoki gyertyános-tölgyesei (Fraxino pannonicae-Carpinetum Soó et BoRHIDI in Soó 1962). - Kaposvári Rippl-Rónai Múzeum Közleményei 1: 17-40.

Kevey B. (2013b): A Bakonyalja homokvidékének erdei IV. Zárt homoki tölgyesek (Polygonato latifolioQuercetum roboris BORHIDI in BORHIDI et KEVEY 1996). - Folia Musei Historico-Naturalis Bakonyiensis 30: 55-82.

Kevey B. (2013c): Korrekció Kevey B. „A Zselic szurdokerdei (Polysticho setiferi-Aceretum pseudoplatani KEVEY in BoRHIDI et KEvEY 1996)” c. tanulmányához (Natura Somogyiensis 17 [2010]: 35-60.). Natura Somogyiensis 23: 33-36.

Kevey B. (2013d): Korrekció Kevey B. A Zákányi-dombok égerligetei (Carici pendulae-Alnetum glutinosae BoRHIDI et KEVEY 1996) című tanulmányhoz [Kanitzia - Botanikai folyóirat (2008-2009) 16: 211-231]. - Kanitzia 20: 241-242.

KeveY B. (2014a): A Kelet-Mecsek gyertyános-tölgyesei. - Oak-hornbeam forests [Asperulo taurinaeCarpinetum (A. O. HoRvát 1958) Soó \& BoRHIdi in Soó 1962] in the eastern Mecsek Mountains. - Acta Naturalia Pannonica 7: 77-114.

KEveY B. (2014b): A Bakonyalja homokvidékének erdei V. Gyertyános-tölgyesek (ConvallarioCarpinetum). - Folia Musei Historico-Naturalis Bakonyiensis 31: 47-72.

KEVEY B. (2015a): Adatok Magyarország flórájának és vegetációjának ismeretéhez X. - Botanikai Közlemények 102 (1-2): 39-60.

KevEY B. (2015b): A Bakonyalja homokvidékének erdei VI. Égerligetek (Aegopodio-Alnetum glutinosae Kárpáti V., KÁRPÁTI I. et JURKO ex ŠomŠÁK 1961). - Folia Musei Historico-Naturalis Bakonyiensis 32: 49-70.

KeveY B. (2015c): A Tengelici-homokvidék zárt homoki tölgyesei (Polygonato latifolii-Quercetum roboris BORHIDI in BORHIDI et KEVEY 1996). - Natura Somogyiensis 27: 5-36.

KeveY B. (2015d): A Nyugat-Mecsek gyertyános-tölgyesei. - e-Acta Naturalia Pannonica 8: 5-41.

KEVEY B. (2015e): A vasi Rába-völgy gyertyános-tölgyesei (Veronico montanae-Carpinetum scilletosum drunensis KeveY subass. nova). - Kanitzia 22: 211-237.

KEVEY B. (2015f): Korrekció: „KEvEY B.: A Bakonyalja homokvidékének erdei V. Gyertyános-tölgyesek (Convallario-Carpinetum KeveY 2008)" c. tanulmányhoz (Folia Musei Historico-Naturalis Bakonyiensis 31 [2014]: 47-72). - Folia Musei Historico-Naturalis Bakonyiensis 32: 47-48.

KEvEY B. (2016): A Villányi-hegység gyertyános-tölgyesei [Asperulo taurinae-Carpinetum (A.O.Horvát 1946) Soó et BorHidi in Soó 1962]. - e-Acta Naturalia Pannonica 10: 21-46.

Kevey B. \& AlEXAY Z. (1992): Adatok a Szigetköz flórájához. - Acta Ovariensis 34(1): 29-37.

Kevey B. \& Baranyi Á. (2002): A Nyugati-Mecsek égerligetei (Carici pendulae-Alnetum Borhidi et KeveY 1996). - Janus Pannonius Múzeum Évkönyve 44-45 (1999-2000): 5-24. 
Kevey B. \& BARNA Cs. (2015): A hazai Felső-Tisza-vidék fűzligetei (Leucojo aestivi-Salicetum albae Kevey in BoRHIDI \& KeVEY 1996). - Kitaibelia 21 (1): 78-100.

Kevey B. \& Borhidi A. (2010): A Nyugati-Mecsek tetőerdei (Aconito anthorae-Fraxinetum orni BoRHIDI et Kevey 1996). - Dunántúli Dolgozatok (A) Természettudományi Sorozat 12: 182-221.

Kevey B., Borhidi A., KlujBer K. (1998): Belső-Somogy homoki bükkösei (Leucojo verno-Fagetum KeveY et BorHidi 1992). - Somogyi Múzeumok Közleményei 13: 241-256.

Kevey B., Horváth A., LendVAi G., Simon Gy., Sonnevend I. (2015): A Zámolyi-medence és környékének zárt lösztölgyesei (Pulmonario mollis-Quercetum roboris KevEY 2008). - Botanikai Közlemények 102: 85-129.

KeveY B. \& HuSZÁr Zs. (1999): A Háros-sziget fehérnyár-ligetei (Senecioni sarracenici-Populetum albae KeveY in BoRHIDI \& Kevey 1996). - Természetvédelmi Közlemények 8: 37-48.

Kevey B., JuHÁsz M., KLUJBER K., BorHIDi A. (1992): A Boronka-melléki Tájvédelmi Körzet védett növényei. - Dunántúli Dolgozatok (A) Természettudományi Sorozat 7: 27-58.

Kevey B. \& Kovács J. A. (2010): A Mura-vidék gyertyános-tölgyesei (Veronico montanae-Carpinetum KEVEY 2008). - Kanitzia 17: 195-221.

Kevey B. \& Kovács J. A. (2011): A Mura-vidék tölgy-kőris-szil ligetei (Carici brizoidis-Ulmetum KeveY 2008). - Kanitzia 18: 195-238.

Kevey B. \& Lendvai G. (2015): A Tengelici-homokvidék gyertyános-tölgyesei (Convallario-Carpinetum KeVEy 2008). - Natura Somogyiensis 26: 5-38.

Kevey B., Lendvai G., Simon Gy. (2014): A Velencei-hegység gyertyános-tölgyesei (Corydali cavaeCarpinetum Kevey 2008). - Kanitzia 21: 219-244.

Kevey B., MAJLÁTH I., MolnáR M. (2016): Changes in the hardwood groves of the Martonvásár manor park (Hungary) in the last 30 years. - Acta Botanica Academiae Scientiarum Hungaricae 58 (3-4): 265286. + Table S1-S3.

KeveY B., Orosz-Kovács Zs., Tóth I., BoRHIDI A. (1992): Adatok a Béda-Karapancsa Tájvédelmi Körzet flórájához. - Dunántúli Dolgozatok (A) Természettudományi Sorozat 6: 13-25.

Kevey B. \& Toldi M. (2013): A Zákányi-dombok égeres mocsárerdei (Angelico sylvestri-Alnetum glutinosae BoRHIDI in BORHIDI \& KeVEY 1996). - Natura Somogyiensis 23: 37-74.

KEVEY B. \& TóTH I. (2000): Adatok a hazai Alsó-Duna-ártér flórájához. - Kitaibelia 5 (1): 131-143.

Kevey B. \& TóTH I. Zs. (2016): Égerlápok a Tengelici-homokvidéken. - Kaposvári Rippl-Rónai Múzeum Közleményei 4: 13-30.

Kevey B. \& Tóth V. (2006): A Baranyai-Dráva-sík fehér nyárligetei (Senecioni sarracenici-Populetum albae KEVEY in BORHIDI \& KEVEY 1996). - Natura Somogyiensis 9: 47-62.

KIRÁLY G. (szerk.) (2009): Új magyar füvészkönyv. Magyarország hajtásos növényei. Határozókulcsok. Aggteleki Nemzeti Park Igazgatóság, Jósvafő, 616 pp.

MAjER A. (1979): Búcsú egy különleges erdőtől. - Erdőgazdaság és Faipar 1979 (3): 10-12.

MÁTHÉ I. (1933): A hortobágyi Ohat-erdő vegetációja. - Botanikai Közlemények 30 (5): 163-184.

MENYHÁRTH L. (1877): Kalocsa vidékének növénytenyészete. - Hunyadi Mátyás Intézet, Budapest, 197 pp.+26 pp.

NikLFeld H. (1971): Bericht über die Kartierung der Flora Mitteleuropas. - Taxon 20 (4): 545-571.

NovACSEK P. (1996): Adatok Somogy flórájához. - Somogyi Múzeumok Közleményei 12: 257-261.

PECK I. Á. (1878): A megye viránya. In: MAJOR P. (szerk.), Mosonymegye monographiája 1. - Czéh Sándor Könyvnyomda, Magyaróvár, pp. 42-68.

Pillich F. (1928): Adatok Tolnavármegye flórájához. - Magyar Botanikai Lapok 26 (1927): 94-97.

Pillich F. (1930): Simontornya és környéke flórája (1921-1930). - Kézirat, 74 pp.

PRISZTER Sz. (1980): Függelék. In: Soó R.: A magyar flóra és vegetáció rendszertani-növényföldrajzi kézikönyve VI. - Akadémiai Kiadó, Budapest, pp. 162-259.

RiEziNG N. (2011): A Győr-Tatai Kisalföld erdei: Tájtörténet és vegetáció. - Tájökológiai Lapok 9 (2): 209-217.

Soó R. (1964): A magyar flóra és vegetáció rendszertani-növényföldrajzi kézikönyve I. - Akadémiai Kiadó, Budapest, $589 \mathrm{pp}$.

STETÁK D. (2000): Adatok a Duna-Dráva Nemzeti Park Gemenci Tájegysége flórájához. - Kitaibelia 5 (1): 145-176.

MÁTHÉ I. (1933): A hortobágyi Ohat-erdő vegetációja. - Botanikai Közlemények 30: 163-184.

TóTH I. (1958): Az Alsó-Dunaártér erdőgazdálkodása a termőhely- és az erdőtípusok összefüggése. Erdészeti Kutatások 1958 (1-2): 77-160.

VöRöss L. Zs. (1988): Adatok a Mezőföld flórájának ismeretéhez. - Botanikai Közlemények 74-75 (1-2) (1987-1988): 121-126.

ZóLYOMI B. (1958): Budapest és környékének természetes növénytakarója. In: PÉCSI M. (szerk.), Budapest természeti képe. - Akadémiai Kiadó, Budapest, pp. 511-642. 


\section{Rövidítések}

Kistájak

\author{
A - Alpokalja \\ B - Bakony \\ Ba - Bakonyalja \\ Bd - Baranyai-dombság \\ BDs - Baranyai Dráva-sík \\ Bk - Bodrogköz \\ BS - Belső-Somogy \\ BSzS - Bereg-Szatmári-sík \\ Cssz - Csepel-sziget \\ DTk - Duna-Tisza köze \\ DZ - Dél-Zala \\ Dv - Duna-vidék \\ ÉZ - Észak-Zala \\ G - Gerecse \\ Gd - Geresdi-dombság \\ H - Hanság
}

\author{
HNs - Harkány-Nagynyárádi-sík \\ J - Jászság \\ K - Kemeneshát \\ Khg - Keszthelyi-hegység \\ Ks - Komáromi-síkság \\ KS - Külső-Somogy \\ KTv - Középső Tisza-vidék \\ Köv - Körös-vidék \\ Kv - Kerka-vidék \\ Má - Mura-ártér \\ Mcs - Mecsek \\ Mf - Mezőföld \\ Mh - Marcali-hát \\ Mm - Marcal-medence \\ Msz - Mohácsi-sziget \\ Ny - Nyírség
}

\author{
R - Rábaköz \\ SDs - Somogyi Dráva-sík \\ Sk - Sárköz \\ Sz - Szigetköz \\ Szd - Szekszárdi-dombság \\ Th - Tolnai-hegyhát \\ Tt - Tiszántúl \\ V - Völgység \\ Vehg - Velencei-hegység \\ Vlhg - Villányi-hegység \\ VRv - Vasi Rába-völgy \\ Vshg - Visegrádi-hegység \\ Zd - Zákányi-dombok \\ Zm - Zámolyi-medence \\ Zs - Zselic
}

\section{ÁNÉR élőhelyek kódjai}

Ac: álló és lassan áramló vizek hínárnövényzete

D5: patakparti és lápi magaskórósok

H4: erdőssztyeprétek, félszáraz irtásrétek, száraz magaskórósok

J1a: füzlápok

J2: Láp- és mocsárerdők

J3: bokorfüzesek

J4: Fűz-nyár ligeterdők

J5: égerligetek

J6: keményfás ártéri erdők

K1a: gyertyános-kocsányos tölgyesek

K2: gyertyános-kocsánytalan tölgyesek

K5: bükkösök

K7a: mészkerülő bükkösök

K7b: mészkerülő gyertyános-tölgyesek

L1: mész- és melegkedvelő tölgyesek

L2a: cseres-kocsánytalan tölgyesek
L2b: cseres-kocsányos tölgyesek

L2x: hegylábi zárt erdőssztyep lösztölgyesek

L4a: zárt mészkerülő tölgyesek

L5: alföldi zárt kocsányos tölgyesek

LY1: szurdokerdők

LY2: törmeléklejtő-erdők

LY4: tölgyes jellegű sziklaerdők és tetőerdők

M1: molyhos tölgyes bokorerdők

M2: nyílt lösztölgyesek

M3: nyílt sziki tölgyesek

M8: száraz-félszáraz erdő- és cserjés-szegélyek

OC: jellegtelen száraz-félszáraz gyepek

OF: magaskórós ruderális gyomnövényzet

P45: fáslegelők, fáskaszálók, legelőerdők, gesztenyeligetek

S2: nemesnyárasok

S5: egyéb ültetett tájidegen fenyvesek

Egyéb rövidítések

! (lelőhelyek után): a szerző által említett helyen a növényt magam is láttam

BP: Magyar Természettudományi Múzeum Herbáriuma, Budapest

ex litt.: ex litteris (írásbeli közlés)

ex verb.: ex verbis (szóbeli közlés)

ined.: ineditum (kiadatlan közlés)

K: Kevey B. ined.

Beérkezett: 2017. 03. 18. • Elfogadva: 2017.10.10. 